\title{
EDITH CAVELL
}

\section{De pROBLEMATISCHE REPRESENTATIE VAN EEN OORLOGSHELDIN}

De Eerste Wereldoorlog staat bij velen in de herinnering als een zinloze strijd, waarin legers elkaar probeerden af te matten in de loopgraven in België en Noord-Frankrijk. Honderdduizenden soldaten gaven hun leven om een klein stuk niemandsland terug te veroveren op de vijand, terwijl de politieke en militaire leiders op een veilige afstand de uitputtingsslag gadesloegen. Uiteindelijk zou de Eerste Wereldoorlog slechts een voorbode zijn geweest voor wat de wereld later te wachten stond toen Hitler zijn expansionistische politiek in praktijk ging brengen. De Tweede Wereldoorlog betekende in vergelijking met de Eerste een duidelijke ideologische strijd. De geallieerden hadden de opdracht om 'het kwaad' te verslaan, omdat de vrijheid van miljoenen burgers in het geding was.

De onduidelijke aanleiding van de Eerste Wereldoorlog heeft geleid tot een verregaande simplificatie, waarbij vele gebeurtenissen in de vergetelheid zijn geraakt. Eén van die gebeurtenissen is de executie van de Britse Edith Cavell. Deze vijftigjarige verpleegster had de leiding over een Belgische verpleegstersschool in Brussel, toen Duitsland de stad veroverde in zijn poging om Frankrijk te verslaan. Tijdens de Duitse bezetting van België functioneerde de school van Cavell als onderduikadres voor voortvluchtige geallieerde soldaten. De verzetsorganisatie waartoe Cavell behoorde, bood deze soldaten de mogelijkheid om via de school te ontsnappen naar het neutrale Nederland. Al in de zomer van I9I5 ontmantelden de Duitsers de organisatie, waarna een rechtszaak werd aangespannen tegen de vijfendertig betrokkenen. Negen van de vermeende kopstukken, onder wie Cavell, kregen de doodstraf opgelegd. Na de uitspraak probeerden ambassadeurs van neutrale landen zonder succes de Duitsers tot inkeer te brengen. Duitsland had net een nieuw beleid ten aanzien van België aangenomen: er moest een einde komen aan de burgerlijke ongehoorzaamheid. Om een duidelijk voorbeeld te stellen naar de Belgische bevolking vond de ochtend direct na de vaststelling van het vonnis de executie van de Belgische architect Philippe Baucq plaats. Daarnaast wilde Duitsland ook een signaal afgeven aan zijn vijanden, de geallieerden. Vandaar dat ook Cavell, als Britse, op de ochtend van I2 oktober I9I5 gefusilleerd werd.

De executie van Cavell was tijdens de oorlog wekenlang voorpaginanieuws. De ophef werd onder meer veroorzaakt door haar onbekendheid bij het grote 
publiek. Daardoor hadden de beide oorlogvoerende partijen alle vrijheid om dit incident te gebruiken om de vijand te wijzen op zijn inferioriteit. Tijdens de oorlog was in deze affaire, al dan niet ondersteund door een nationale propagandadienst, een belangrijke rol weggelegd voor de pers en andere invloedrijke verspreiders van informatie. Zowel journalisten, handelaren in oorlogsmemorabilia als kunstenaars hadden door de geringe kennis van het leven van Cavell de mogelijkheid om de gebeurtenis op elke gewenste manier te interpreteren. De representaties die dat proces opleverde zijn tot op heden nauwelijks bestudeerd, terwijl de verschillende weergaven van Cavell aanwijzingen vormen op welke manier men betekenis probeerde te geven aan de Eerste Wereldoorlog. Na de oorlog nam de Britse overheid het initiatief over en dicteerde via herdenkingsdagen en monumenten de wijze waarop Cavell in de herinnering moest blijven. Toch lieten verschillende groeperingen publiekelijk weten geen genoegen te nemen met de officiële interpretatie van Cavells nagedachtenis. De discussie over haar executie bereikte daardoor in I928 een nieuw hoogtepunt naar aanleiding van het nieuws dat er een film over haar laatste levensjaar gemaakt zou gaan worden.

\section{De reacties op de executie}

De executie van Cavell was in I9I5 één van de meest besproken onderwerpen in het publieke debat bij de geallieerden, de Centralen en de neutrale landen. Vooral de oorlogvoerende partijen waren van meet af aan zeer verontwaardigd. Zeker in de eerste weken na I2 oktober waren de reacties zeer emotioneel, soms zelfs op het hysterische af. Dit valt voor een groot gedeelte te verklaren uit de verstandhouding tussen de betreffende overheden, de pers en de bevolking. Omdat de vechtende landen toch een beslissing wilden forceren na het ontstaan van de patstelling aan het westelijk front, grepen legerleiders en regeringen naar andere middelen. De Eerste Wereldoorlog ontaardde in een totale oorlog, waarin het het doel was om een vijandelijk land op elke mogelijke manier te ontwrichten. In plaats van een strijd tussen twee legers op een afgelegen slagveld, werd de Eerste Wereldoorlog de eerste oorlog die deel uitmaakte van de dagelijkse realiteit van de burgers. Deze totale oorlog impliceerde naast conflicten op militair en economisch niveau ook een strijd om de publieke opinie.

In de fase waarin de oorlogvoerenden waren beland vanaf het voorjaar van I9I5, was de controle over alle officiële en onofficiële communicatie dus opeens van groot belang geworden om de moraal van het volk op één lijn te houden met het regeringsbeleid. Veel landen creëerden direct na het uitbreken van de oorlog één of meerdere organisaties, die verantwoordelijk waren voor de uitvoering van censuur en propaganda. In het geval van Groot-Brittannië en Duitsland was de eerste reactie op dit vlak van negatieve aard: de regeringen wilden alle binnenlandse en buitenlandse uitingen kunnen censureren. ${ }^{\mathrm{I}}$ Maar al snel kregen zij 
door dat een positieve stimulans ten opzichte van de nationale oorlogsinspanning ook noodzakelijk was. De propagandadiensten werden ingeschakeld om het vuur opnieuw op te stoken toen het aanvankelijke enthousiasme voor de oorlog onder de bevolking langzaamaan wegebde. Daarnaast waren zij verantwoordelijk voor het tweespalt zaaien onder de bevolking en soldaten van de vijandelijke landen en moesten zij neutrale landen overtuigen van het gelijk dat het desbetreffende oorlogvoerende land meende te hebben.

Duitsland had al enigszins geanticipeerd op een dergelijke strijd door Duitse organisaties in het buitenland in de vooroorlogse jaren te gebruiken als een semi-officieel propagandanetwerk. Toch zorgde de hiërarchische structuur in de politieke besluitvorming voor een relatief ongecoördineerde manier van productie en distributie van propaganda. ${ }^{2}$ De regering en het leger hadden namelijk een behoorlijk wantrouwen in de berichtgeving door de Duitse pers, waardoor de pers zeer strikte regels opgelegd kreeg. De initiator in deze kwestie was de Duitse legerleiding, die bovendien door het uitbreken van de oorlog de verantwoordelijkheid had gekregen voor de propagandadiensten. Door het vastlopen van de Blitzkrieg belandden die echter in een lastig parket. In eerste instantie beriep Duitsland zich op zijn defensieve motieven, omdat het land omringd zou zijn door expansionistische buurlanden. De bezetting van België was door tegenstanders alleen makkelijk te interpreteren als het tegendeel, waardoor de Duitse propagandadiensten over het algemeen gedwongen waren om te reageren op beschuldigingen van binnenlandse en buitenlandse critici. Duitsland verloor daardoor enigszins het initiatief in de oorlog om de publieke opinie.

Groot-Brittannië had voor de Eerste Wereldoorlog nauwelijks ervaring met de productie van propagandamateriaal, maar door de ontstane situatie werden de Britten gedwongen om snel actie te ondernemen. Ten opzichte van de berichtgeving aan het buitenland borduurden de propagandisten voort op de manier van werken van de Engelse diplomaten, waarbij persoonlijk contact voorop stond. Door buitenlandse opiniemakers op informele wijze te informeren, hoopten de Engelsen op indirecte wijze buitenlandse bevolkingen te beïnvloeden. Bovendien zorgde deze methode ervoor dat Engeland niet door buitenlandse regeringen beschuldigd kon worden van ongeoorloofde inmenging. In tegenstelling tot Duitsland bleek in eigen land strenge censuur overbodig te zijn, omdat de Engelse pers zich een gewillig dienaar van de propagandamachine toonde. ${ }^{3}$ Met deze wetenschap ontwikkelden de propagandadiensten de strategie om vaak maar een deel van de feiten naar buiten te brengen, zodat de pers ermee aan de haal kon gaan. Op deze manier verschenen in korte tijd de meest fantasievolle verhalen, die zich op de lange termijn zelfs konden ontwikkelen tot diepgewortelde mythen in het (inter)nationale geheugen.

In de affaire Cavell speelden twee Britse publicaties een belangrijke rol. Allereerst lekte de correspondentie over Cavell tussen de Britse, Amerikaanse en Duitse diplomaten uit, tot grote verontwaardiging van de Duitsers. Ze rekenden deze breuk met de diplomatieke etiquette voornamelijk de Amerikanen aan, 
De foto van de

opgraving van

Rammler (1915).

Bron: http://

www.ww1-

propaganda-cards. com/miss_edith_ cavell.html

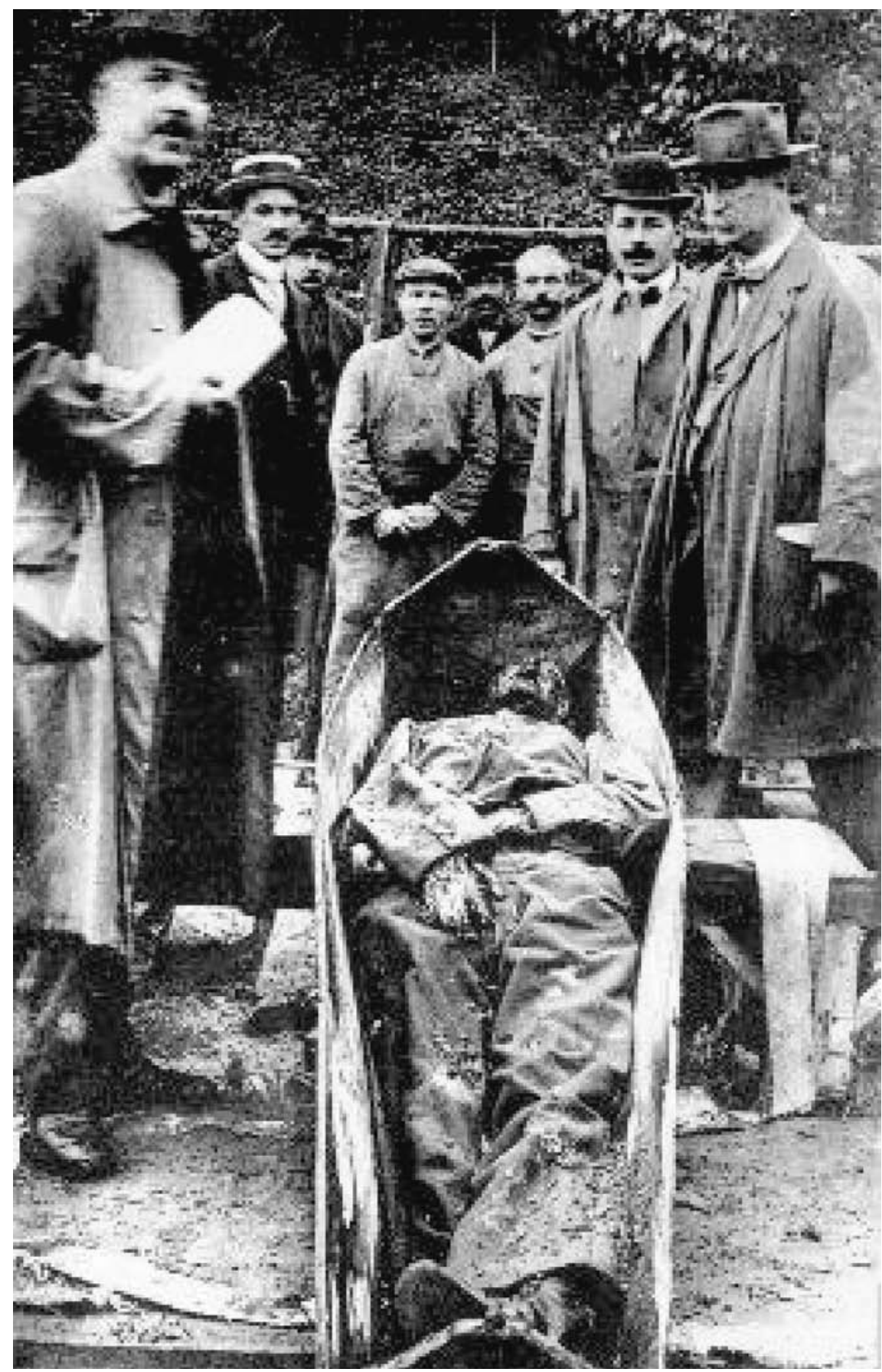


omdat die optraden als vertegenwoordigers van de Britse belangen in het bezette gedeelte van België. De Amerikaanse ambassadeur beweerde echter niets met deze actie te maken te hebben, omdat de correspondentie ongevraagd door de Engelsen was gepubliceerd. Inhoudelijk viel deze publicatie overigens behoorlijk mee, in tegenstelling tot de suggestieve brochure The death of Edith Cavell. Deze brochure van een anonieme auteur was uitgegeven door het War Propaganda Bureau, de meest actieve (semi-officiële) propagandadienst, beter bekend als Wellington House. Typerend voor alle publicaties van dit instituut was de vlaag van wetenschappelijke objectiviteit, waardoor veel beweringen overtuigend over kwamen. Al snel was The death of Edith Cavell een groot succes in Groot-Brittannië en andere geallieerde en neutrale landen, niet in de laatste plaats geholpen door de lage aanschafprijs.

Toch liet de informatievoorziening te wensen over. De veelvuldige speculaties over de ochtend van de executie werden niet ontkracht, waardoor er in de media al snel de wildste spookverhalen verschenen. Allereerst was er het gerucht dat een Duitse soldaat uit Cavells vuurpeloton, Rammler, had geweigerd te schieten op een vrouw. Daarop zou hij ter verantwoording zijn geroepen, maar dat mocht niet baten: Rammler bleef bij zijn standpunt. Hij werd ter plekke neergeschoten door zijn meerdere. Deze soldaat zou vervolgens op dezelfde plek begraven zijn als Cavell en Baucq. Als bewijs deed een zeer populaire ansichtkaart de ronde, waarop een foto van een doodgeschoten soldaat afgedrukt was. Het geloof in de betrouwbare weergave van de werkelijkheid van de realiteit door een fotocamera was nog zo wijdverbreid, dat weinig mensen zich konden voorstellen dat dit voorval niet had plaatsgevonden. ${ }^{4}$ Toch is dit verhaal een misverstand gebleken, omdat het een geëxecuteerde Duitse onderofficier was, die informatie had doorverkocht aan geallieerde spionnen. Zijn executie had in september I9I5 plaatsgevonden en toevalligerwijs werden Cavell en Baucq naast hem begraven. Op de foto is hij naar alle waarschijnlijkheid wel afgebeeld, maar dit werd uit de context gehaald ter bevordering van de verontwaardiging over de executie van Cavell.

Het andere gerucht ging over Edith Cavell zelf, omdat zij geweigerd zou hebben een blinddoek om te doen. Op het moment dat het vuurpeloton vervolgens het bevel kreeg om aan te leggen, zou Cavell zijn flauwgevallen. De bevelhebbende Duitse officier zou daarna naar haar zijn toegelopen en haar, terwijl ze nog buiten bewustzijn was, met zijn eigen pistool hebben doodgeschoten. Uit getuigenverslagen en een sectieonderzoek na de oorlog bleek dat haar executie normaal was verlopen, zonder datéén van de bovenstaande gebeurtenissen was voorgevallen.

Afgezien van de twee bekendste geruchten gaf Cavells executie de Britten genoeg redenen om Duitsland zwart te maken, zoals dat sinds de inval in poor little Belgium al gebeurde. Allereerst waren de Britten verontwaardigd dat de Duitsers een vrouw ter dood veroordeeld hadden. Dat was ten tijde van de oorlog voor menigeen zeker nog een argument dat op kon gaan. Bovendien had Cavell 
een nobel en altruïstisch beroep. Na de bezetting van Brussel door het Duitse leger waren door haar zorgen als zuster Duitse soldaten weer gezond geworden. In Groot-Brittannië werden de Duitsers daarnaast veroordeeld voor de snelle uitvoering van het vonnis zonder dat dit van tevoren publiek bekend was gemaakt. Door deze geheimhouding hadden de Britten de indruk dat de Duitsers zich eigenlijk wel bewust waren geweest van de onrechtvaardigheid van hun beslissing.

Het bewijs van het succes van de Britse retoriek uitte zich onder andere in een hausse aan nieuwe aanmeldingen voor het Britse leger. De gekrenkte nationale trots zorgde zeker zes weken lang voor een enorme opleving. ${ }^{5}$ De officiële Duitse reactie, die bepaald werd door het leger, gooide in dezelfde periode zelfs nog olie op het vuur. Duitsland ontkende halsstarrig de beschuldigingen en wees op de grove overtreding die Cavell had begaan binnen het Duitse rechtssysteem door de vijand van manschappen te voorzien. Typerend voor de stemming in Duitsland (en de kracht van de verzonnen verhalen) was de uitspraak van Thomas Mann in Betrachtungen eines Unpolitischen. Hij meende dat iemand die de dood niet in de ogen durfde te kijken door flauw te vallen, zich ook niet moest bemoeien met oorlogszaken. ${ }^{6}$ Later probeerde keizer Wilhelm i n nog wel de gemoederen te bedaren door te bepalen dat voortaan alle executies van vrouwen eerst aan hem voorgelegd moesten worden. Bovendien moest de verdediging wel de kans krijgen om in beroep te gaan tegen een eventueel doodvonnis. ${ }^{7}$ Deze compensatiemaatregelen sorteerden weinig effect, want de Britse propagandadiensten hadden in samenwerking met de zogenaamd onafhankelijke pers hun werk goed gedaan.

Ondanks de grote aandacht voor Cavell in de media is het noodzakelijk om de invloed en de rol van propaganda te nuanceren. Het feit dat de oorlogvoerende landen hun handen vol hadden aan het onder controle houden van alle vormen van communicatie, betekent niet direct dat alle bezigheden ook nuttig waren. Historicus Trevor Wilson stelt dat het toeschrijven van een doorslaggevende rol aan propaganda in het bereiken van de geallieerde overwinning het omdraaien van oorzaak en gevolg is. ${ }^{8}$ Volgens hem was het succes van propaganda voor het grootste gedeelte afhankelijk van de overwinning zelf, waarop de propagandamakers vervolgens konden meeliften. Afgezet tegen het algehele verloop van de Eerste Wereldoorlog heeft de affaire Cavell daaraan weinig toegevoegd, behalve dan dat zij postuum wereldwijde bekendheid kreeg.

\section{De representaties tijdens de oorlog}

Naast de effectieve samenwerking tussen de Britse overheid en de pers in de strijd om de publieke opinie, valt het succes van het Britse perspectief op de gebeurtenissen rond Cavell te verklaren vanuit een meer algemene tegenstelling tussen de twee oorlogvoerende partijen. Beide meenden namelijk dat hun 
eigen cultuur superieur was aan die van de tegenstander. Zo werd de Eerste Wereldoorlog dus ook een strijd tussen de geallieerde civilization en de Duitse Kultur. De oorsprong van deze gedachten stamde al uit het einde van de achttiende eeuw. Duitsland, dat toen nog geen staatkundige eenheid vormde, wilde zich afzetten tegen de dreiging die van Frankrijk en de Franse Revolutie uitging. Vandaar dat Duitse intellectuelen op zoek gingen naar een gezamenlijke basis die niet politiek georiënteerd was. Omdat Duitsland in een culturele bloeiperiode verkeerde, meenden zij dat de Volksgeist, een idee voortgekomen uit de Romantiek, bepalend was voor de Duitse identiteit. Alle Duitsers maakten deel uit van dezelfde volksgemeenschap, die een levendig organisch geheel vormde. De Franse Staatsnation werd vergeleken met een rationalistische constructie die onmogelijk dezelfde continuiteit kon bieden als de Duitse Kulturnation. ${ }^{9}$

Bij het begin van de Eerste Wereldoorlog werd deze tegenstelling opnieuw aangehaald. Deze keer was het niet alleen Duitsland dat zich afzette, maar ook Frankrijk en Groot-Brittannië gingen de Kulturkampf aan. De geallieerden bestreden het beeld dat de Duitsers van zichzelf hadden. Volgens hen was de aard van de Duitse geest niet eenvoudig, moedig en eerlijk, maar juist onderontwikkeld en barbaars. Ze gebruikten voornamelijk de verwijzing naar de Hunnen, het 'barbaarse' Mongoolse volk dat in de vierde en vijfde eeuw na Christus Europa was binnengevallen en zelfs het 'Germaanse' grondgebied had bereikt. De Hun werd het stereotype om de immoraliteit van het 'Pruisische militarisme' aan te tonen. Deze immoraliteit had immers gezorgd voor het ontstaan van de oorlog, omdat Duitsland de internationale wetgeving had geschonden met de inval in het neutrale België. De onophoudelijke stroom van berichten van zogenaamde excessen in België, zoals de executie van Cavell, gaf de geallieerden een schijnbaar onuitputtelijke bron om dit standpunt van voorbeelden te voorzien.

De Kulturkampf had een specifieke functie voor beide partijen. Door te wijzen op de essentiële verschillen tussen de eigen partij en de tegenstander maakten de regeringen de noodzaak van de oorlog duidelijk. In eerste instantie leek dit alleen nodig voor een relatief korte periode, maar door het ontstaan van de loopgravenoorlog was deze 'culturele mobilisatie' ook noodzakelijk om de bevolking te overtuigen van een langere oorlogsinspanning. ${ }^{\text {Io }}$ Het grote voordeel was dat de pleidooien over de tegengesteldheid van de beide culturen tot in alle lagen van de bevolkingen waren doorgedrongen. De propagandadiensten hadden daardoor tijdens de oorlog voornamelijk een ondersteunende functie, omdat veel burgers zichzelf al cultureel gemobiliseerd hadden.

Zodoende werd het duidelijk dat velen de gebeurtenissen rond Cavell wilden blijven herinneren. Vooral in visuele uitingen kwamen de culturele (zelf)mobilisatie en de beeldvorming van Cavell als heldin en de Duitsers als barbaren duidelijk naar voren. Tekeningen en - in mindere mate - foto's in kranten en geillustreerde magazines, op posters, ansichtkaarten en postzegels konden tijdens de oorlog een zeer grote doelgroep bereiken. De manier waarop het verhaal van 
De ansichtkaart van Emile Pastien (1915). Bron: S. Upjohn, Edith Cavell. The story of a Norfolk nurse, Norwich 2000, p. 41

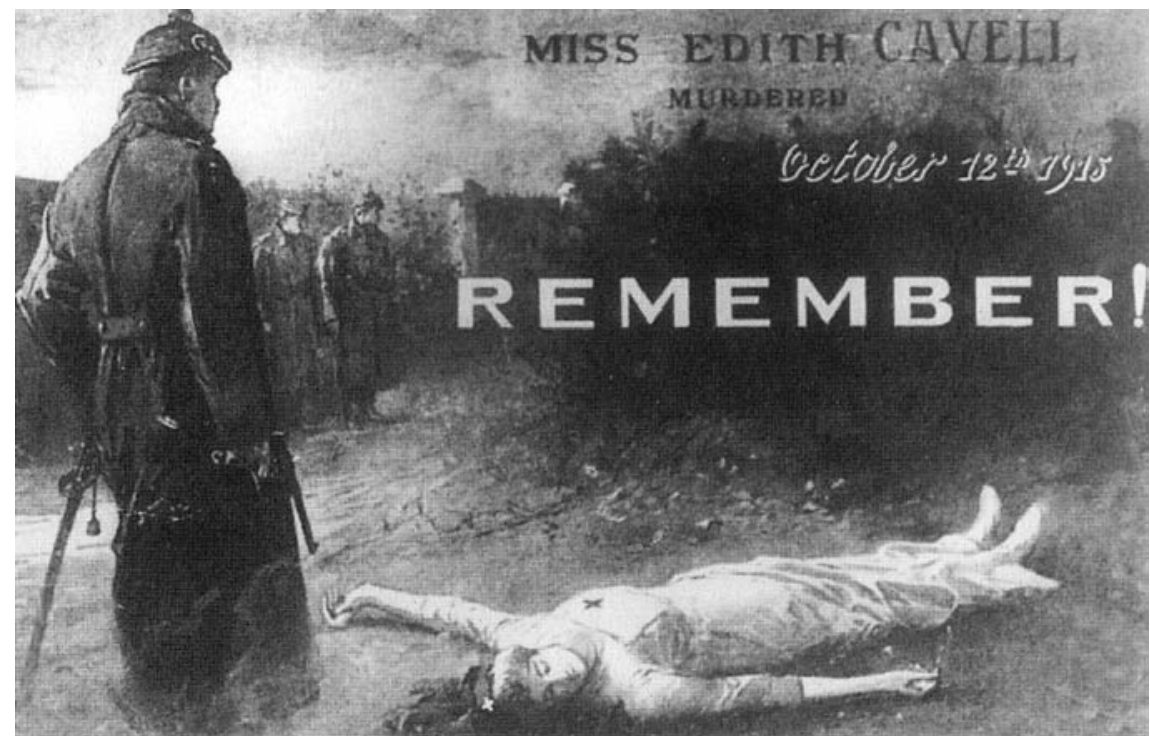

Cavell in herinnering werd gebracht verschilde vaak van object tot object. Maar ondanks de verschillen deden alle representaties een beroep op de verheffing van Cavell tot martelares. Omdat zij haar verzetsactiviteiten ten behoeve van de geallieerde belangen in het algemeen en haar vaderland in het bijzonder met de dood had moeten bekopen, vonden de geallieerden dat zij een schuld in te lossen hadden. Haar opoffering gaf aan dat zij haar eigen leven ondergeschikt had geacht aan de (inter)nationale belangen. Tegelijkertijd bewees ze daarmee de superioriteit van de geallieerde civilization ten opzichte van de Duitse Kultur.

Een goed voorbeeld van een populaire representatie van Cavell is te zien op een ansichtkaart van de Franse kunstenaar Emile Pastien. De symboliek op deze kaart is in talloze variaties gepubliceerd. Historica Catherine Speck noemt de afbeelding van de gebeurtenissen rond Cavell zoals op deze kaart één van de twee belangrijkste vormen van haar representatie. ${ }^{\text {II }}$ De ansichtkaart doet een groot beroep op de emoties van de kijker, omdat Cavell is afgebeeld als een meisjesachtig en onschuldig slachtoffer van een meedogenloze vijand zonder gevoel voor eer. Door haar af te beelden als een jonge vrouw, benadrukt Pastien de maagdelijkheid en dus het onrecht dat de Duitsers haar hadden aangedaan. De zusterskleding stelt de daad van de Duitsers, zoals verondersteld in één van de geruchten, in een nog kwader daglicht. In een wit tenue van het Rode Kruis ligt Cavell dood op de grond, terwijl allang naar voren was gekomen dat zij haar proces en executie in burgerkleding had ondergaan. Pastien doet daarmee een beroep op een belangrijke aan vrouwen toegewezen eigenschap: zorgzaamheid. ${ }^{\text {I2 }}$

Pastien heeft Cavell zo afgebeeld dat zij iedereen aan kon spreken. Door het vermijden van uiterlijke gelijkenissen met de echte Cavell had eenieder de mogelijkheid om haar te identificeren met een vrouw uit zijn of haar omgeving. Hij 
doet daar nog een schepje bovenop door haar een fictieve seksuele aantrekkingskracht te geven, die versterkt wordt door het ontbreken van een wond of een spoor van bloed. De kaart suggereert daardoor dat de Duitse officier met zijn pistoolschot Cavell heeft verkracht. Het pistool kan zelfs geïnterpreteerd worden als het fallussymbool op deze afbeelding. ${ }^{\mathrm{I}}$ Dit paste niet alleen goed bij de situatie van Cavell, maar had ook een meer alomvattende betekenis: de 'verkrachting' van België. De officier representeert in dat geval Duitsland, Cavell is België en de executie staat voor alle misdaden die de Duitsers in België hadden begaan.

Een andere kunstenaar, de Italiaan Tito Corbella, raakte ook geïnspireerd door de executie van Cavell. Hij maakte een zesdelige serie schilderijen, die ook als ansichtkaarten op de markt kwamen. Cavell is wederom afgebeeld als een zuster van het Rode Kruis, waardoor associaties met vrouwelijke karaktereigenschappen worden opgeroepen. Met het doek “'Kultur” threatens Miss Cavell' verduidelijkt Corbella wat hij associeert met de westerse beschaving, namelijk barmhartigheid. Cavell verzorgt dankzij haar onpartijdigheid een vijand, terwijl de wereld achter haar in brand staat, oftewel, terwijl de Eerste Wereldoorlog wordt gevoerd. Corbella is zeker niet de enige die gebruik maakte van dit religieuze thema, maar toch waren er maar weinig kunstenaars die Cavell afbeeldden terwijl ze een Duitse soldaat verzorgde. De aandacht voor haar verzetswerk is in de herinneringscultus over het algemeen klein. Om de tegenstelling zo scherp mogelijk te stellen, gingen kunstenaars op zoek naar de grootst moge-

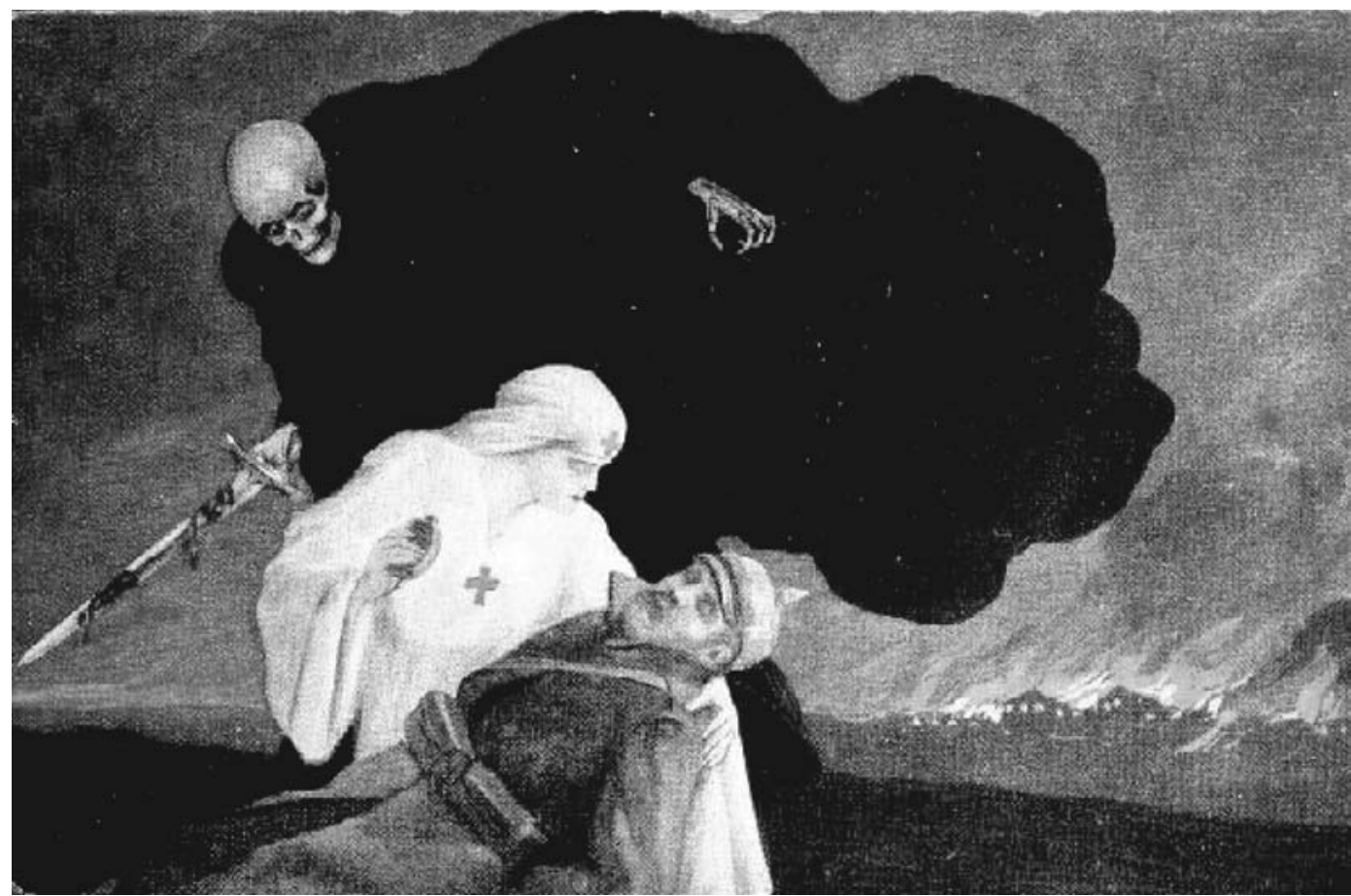

“Kultur” threatens Miss Cavell'van Tito Corbella (1915). Bron: http://www.ww1-propaganda-cards.com/miss_edith_cavell.html 
lijke effectiviteit. De verheerlijking kwam dan het best tot uiting in de afbeelding van de executie. Haar berusting in het ondergaan van haar lot en het barbaarse optreden van de Duitsers vormde de grootste tegenstelling in de strijd tussen beide culturen.

De zuster als angel of mercy was trouwens een typisch verschijnsel dat ontstaan was in de tweede helft van de negentiende eeuw. ${ }^{\mathrm{I}} \mathrm{Na}$ de bekendmaking van de daden van Florence Nightingale ontstond deze vergelijking, die noodzakelijk werd geacht door de professionalisering van de verpleegkunde. Voorheen hadden nonnen de taak op zich genomen om zieken te verzorgen, maar de professionele zusters hadden een minder 'directe' band met God. Door deze modernisering was een nieuwe aanvaardbare invalshoek nodig, die gebaseerd was op meer traditionele denkbeelden. De moderne zuster werd voortaan gezien als een nobele jonge vrouw met een goed moreel inzicht en een sterke geloofsovertuiging. Twee andere eigenschappen die voorheen aan nonnen werden toegeschreven, konden ook in dit beeld ingepast worden. De professionele zuster was door haar jeugdige leeftijd nog een maagd en toonde geen enkel bezwaar om zichzelf op te offeren ten behoeve van een hoger ideaal: het zorgen voor de mensheid. Deze beeldvorming toont aan waarom kunstenaars tijdens de Eerste Wereldoorlog geen enkel probleem hadden om Cavell te vervangen door een willekeurige jonge zuster. Op die manier vergrootten zij de aantrekkingskracht en de herkenbaarheid van hun werk. De vijftigjarige Cavell paste met haar leeftijd en sobere burgerkleding maar gedeeltelijk in de boodschap die ze over wilden brengen. Ze functioneerde voornamelijk als inspiratiebron, terwijl haar bekendheid tegelijkertijd de eerste aanzet voor burgers kon zijn om hun werk aan te schaffen.

De schilderijen van Corbella wijken wel af van andere werken door hun heftigheid. Ze appelleren aan een macaber mythisch avontuur, waarin er alleen plaats is voor het onderscheid tussen goed en kwaad. Hij presenteert de strijd tussen de beide culturen als een klassiek gevecht dat al eeuwenlang gevoerd wordt. De tegenstelling tot Cavells afbeelding als de ontwikkelde westerse cultuur is het skelet in het zwarte gewaad: de representatie van de Duitse Kultur. Corbella stelt de essentie van de Duitse cultuur gelijk aan de dood, in plaats van het beeld van Dichter und Denker dat de Duitsers zelf als ideaalbeeld hadden.

De witte kleding van Cavell in de representaties van Pastien en Corbella roept ook nog een andere associatie op. Naast haar representatie van onschuld en maagdelijkheid is zij afgebeeld als een moderne heilige. ${ }^{15}$ Een vergelijking met Jezus Christus is daardoor mogelijk. Cavell had haar leven vrijwillig gegeven voor haar vaderland en bondgenoten, terwijl ze ook nog Duitse soldaten had verzorgd. Ze had zichzelf opgeofferd voor de mensheid, net zoals Jezus het lijden van de wereld op zich had genomen. Beiden werden daarvoor bestraft met de dood en deden geen poging om dit lot te ontlopen. De standvastigheid tot in de dood was het teken van het geloof in hun overtuiging. Vandaar dat van het verhaal van Cavell een universele betekenis kon uitgaan, waar de geallieerden 
graag gebruik van wilden maken. Door de nadruk te leggen op haar overtuiging en toewijding legden de geallieerden een direct verband tussen hun partij en God. Dit was de ultieme rechtvaardiging van de oorlog tegen de Centralen. Wie God aan zijn kant had, kon onmogelijk inferieur zijn ten opzichte van zijn tegenstanders. ${ }^{16}$

De representaties van Cavell als jonge vrouw laten haar zien als weerloos slachtoffer. Daarvan is weinig sprake in de tweede categorie die Catherine Speck onderscheidt. ${ }^{\text {I7 }}$ Cavell wordt daarin afgebeeld als een volwassen en moedige vrouw, die vaderlandsliefde en waardigheid hoog in het vaandel heeft staan. Deze afbeeldingen zijn realistischer van aard, waardoor Cavell de uitstraling heeft van een moeder in plaats van een onschuldige jonge vrouw. In letterlijke zin is dat een vreemde associatie, omdat ze nooit getrouwd is geweest en nooit kinderen heeft gekregen. De eigenschappen van een moeder werden dan ook niet geprojecteerd op haar privé-leven, maar op de geallieerde bevolkingen in het algemeen en de Britse natie in het bijzonder. ${ }^{\text {I8 }}$ Ze was als zuster degene geweest die soldaten had verzorgd en getroost. De meeste soldaten hadden trouwens haar zonen kunnen zijn. Daarmee nam ze de rol over van hun moeders aan het thuisfront en werd ze een voorbeeld voor vrouwen in de oorlog. De toenmalige Britse premier Asquith maakte daar dankbaar gebruik van in zijn toespraak kort na het overlijden van Cavell:

'She has taught the bravest man amongst us a supreme lesson of courage; and in this United Kingdom and through the Dominions of the Crown there are thousands of such women, but a year ago we did not know it.' ${ }^{\text {I9 }}$

Het bekendste voorbeeld uit deze categorie is een foto van Cavell in de tuin van haar École d'Infirmières Diplômées in Brussel. Deze foto was tijdens (en na) de oorlog een zeer geliefde afbeelding, omdat het appelleerde aan een typisch Brits ideaal: het pastorale leven. Het gras, de honden en de struiken op de achtergrond lieten Cavell zien als een echte Britse in een typisch Brits natuurlandschap. De Britten zagen dit traditionele en oer-Britse plattelandsleven als het ultieme ideaal. ${ }^{20}$ Het is

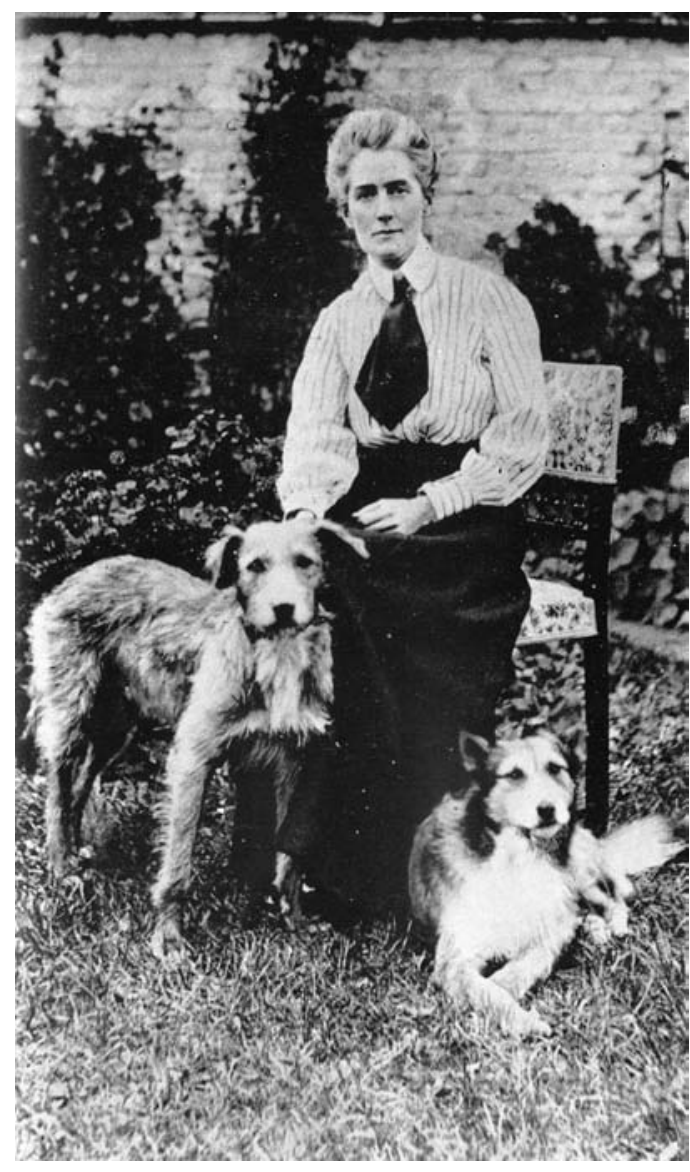

Edith Cavell met haar honden Don en Jack (1914) Bron: A.E. Clark-Kennedy, Edith Cavell. Pioneer and patriot, Londen 1965, p. 224 
begrijpelijk dat dit soort paradijselijke oorden aan aantrekkingskracht wonnen tijdens de barre omstandigheden van de oorlog. Paradijselijke taferelen boden het soort houvast dat nodig was om de gebeurtenissen tijdens de Eerste Wereldoorlog te kunnen verwerken. De foto van Cavell liet de Britten zichzelf zien, zoals ze zichzelf het liefste zagen. Ook andere oorlogsmemorabilia met afbeeldingen van Cavell droegen bij aan dit 'trivialiseringsproces', zoals historicus George Moss dit noemt. ${ }^{2 \mathrm{I}}$ Dit proces makkte de oorlog en de oorlogservaring behapbaar in tegenstelling tot de min of meer abstracte verhalen over troepenmanoeuvres, aanvalsstrategieën en leefomstandigheden aan het front. De oorlog werd op die manier gemeengoed, zonder dat het een beangstigende of te overdonderende indruk achterliet bij de bevolking aan het thuisfront.

Deze tweede categorie representaties geeft Cavell een strijdvaardiger karakter dan wanneer zij als jonge vrouw is afgebeeld. Sommige afbeeldingen vertonen zelfs overeenkomsten met de verering van omgekomen soldaten door de begeleidende teksten of omdat Cavell een das draagt. Dit was een belangrijk aspect in de al eerder aangehaalde transformatie tot heilige, dat minder duidelijk naar voren komt in Cavells afbeeldingen als jonge vrouw. Om tot een heilige te kunnen worden uitgeroepen moet een persoon aan twee voorwaarden voldoen. ${ }^{22}$ Ten eerste moet diegene over heroïsche deugden beschikken, waar geen enkele omstandigheid invloed op kan uitoefenen. Dit vereist een absolute orthodoxie ten opzichte van de zaak waarvoor gestreden wordt. Daarnaast moet deze instelling leiden tot levensbedreigende situaties, die veelal eindigen met de dood. Dan kan deze persoon tot martelaar uitgeroepen worden. Op die manier raken stoïcijnse vaderlandsliefde en christelijk martelaarschap met elkaar verweven, omdat de nadruk komt te liggen op moed, onwrikbaarheid en plichtsgetrouwheid. Door Cavell te presenteren als een volwassen en vastberaden vrouw met extreme deugdzaamheid steeg zij boven de 'normale' mensen uit en werd ze een heldin en heilige.

De herinneringscultus rond Cavell bevestigt daarmee de visie van historicus Jay Winter. ${ }^{23}$ De Eerste Wereldoorlog vormde geen radicale breuk in de westerse cultuurgeschiedenis, zoals lang werd gedacht. Tijdens de oorlog gingen veel mensen op zoek naar manieren om alle gebeurtenissen te kunnen verwerken, waarbij ze over het algemeen teruggrepen op traditionele uitingsvormen. Deze waren dan misschien minder intellectueel hoogstaand, maar boden wel de geruststelling en voldoening die velen nodig hadden. De representaties van Cavell interpreteren haar verhaal voornamelijk vanuit een religieus perspectief. Cavell is een heilige of angel of mercy, terwijl de Duitsers nakomelingen van de duivel zijn. De afbeeldingen met Cavell als jonge vrouw hebben voornamelijk tot doel om Duitsers en hun Kultur zwart te maken. Cavells rol is gemarginaliseerd tot hulpeloos slachtoffer van barbaarse gewelddadigheid. Op die manier benadrukten de makers het onrecht dat haar, de geallieerden en de hele westerse civilization was aangedaan. De meer realistische afbeeldingen hadden 
daarentegen de functie om de eigen partij te verheerlijken. Door de impliciete heiligverklaring van Cavell maakten de geallieerden duidelijk dat zij de vrouwelijke modelburger was van de westerse samenleving in oorlogstijd. Haar opoffering gaf de geallieerden in het algemeen en de Britten in het bijzonder een positie van ethische onaantastbaarheid. Door haar executie kregen de geallieerden de mogelijkheid om zich al tijdens de oorlog uit te roepen tot morele winnaars. De uiteindelijke militaire overwinning voorzag deze claim van een vernieuwde en langdurige legitimiteit.

\section{De nagedachtenis van Cavell}

Ongeacht de uitkomst van de oorlog had elk land een groot verlies aan mensen te verwerken. Vrijwel iedereen uit een voormalig oorlogvoerend land had het overlijden van een naaste te betreuren. Vandaar dat men na de oorlog in alle landen op zoek ging naar een manier om dit gevolg van de oorlog te verwerken. Zo ontstonden allerlei initiatieven op nationaal en lokaal niveau om het rouwproces van de burgers collectief en individueel te begeleiden. Het uitgangspunt in dit proces was om een balans te zoeken tussen herinneren en vergeten. Het herinneren was van belang om iedereen die zijn leven had gewaagd van een passend en blijvend eerbetoon te voorzien. Op deze manier kregen de slachtoffers en de overlevenden de aandacht die zij verdienden. Het vergeten van de oorlog had ook een belangrijke functie, omdat de Eerste Wereldoorlog aanvoelde als de grootste catastrofe die de mensheid zichzelf ooit had aangedaan. Na de wapenstilstand wilden velen niets liever dan vooruitkijken, om zodoende te kunnen bouwen aan een nieuwe toekomst. In dit gebied, tussen herinneren en vergeten, probeerden de nabestaanden te zoeken naar de betekenis van de Eerste Wereldoorlog. ${ }^{24}$ Maar door de enorme omvang van de oorlog en de nog niet eerder vertoonde gevolgen van grootschalige destructie, was het niet makkelijk om tot zingeving te komen.

Voor het Britse volk was Cavell na haar dood uitgegroeid tot een martelaar en nationale heldin. In tegenstelling tot de anonimiteit waarin de soldaten waren omgekomen, spraken de omstandigheden rond Cavell sterker tot de verbeelding. Haar leven leek meer op het leven van de gemiddelde Britse burger dan dat van de soldaten. Cavell woonde in een herkenbare omgeving, een stad, en hield zich tot op zeker hoogte bezig met alledaagse beslommeringen. Dit was van groot belang voor het voorstellingsvermogen van de Britten, waardoor zij, als individu, een belangrijke rol speelde in het toekennen van betekenis aan de Eerste Wereldoorlog. Het individuele verhaal van Cavell maakte de oorlog inzichtelijk - in tegenstelling tot de berichten over het front. Dit resulteerde in een grootscheeps georkestreerde repatriëring in I9I9. In aanwezigheid van koningin Alexandra vond op I5 mei een officiële dienst plaats in Westminster Abbey, die voorafgegaan was door een processie door de straten van Londen. 
De Britse herdenking van de Onbekende Soldaat, die voor het eerst plaatsvond op II november I920, had ongeveer dezelfde toon als de herdenking van het overlijden van Cavell. Beide evenementen waren erop gericht om de overlevenden troost te bieden. Daardoor viel de nadruk meer op de positieve elementen van de oorlog dan op de negatieve. Dit is niet zo vreemd, omdat beide herdenkingen waren georganiseerd door een aan de overheid verbonden instantie. De boodschap was dat de Eerste Wereldoorlog een nobele en verheffende gebeurtenis was geweest, met ontegenzeggelijk ook tragische kanten. Deze mochten echter niet het grote doel overstemmen, omdat de gevallenen hadden gevochten voor de eer en het voortbestaan van de natie. De overeenkomst tussen beide gebeurtenissen werd gesymboliseerd door de Union Jack. Het exemplaar dat de kist van de Onbekende Soldaat bedekte, was ook gebruikt bij Cavell. ${ }^{25}$ Op die manier functioneerde de Onbekende Soldaat als herinnering aan alle gesneuvelde mannen, terwijl Cavell het symbool werd voor alle gesneuvelde vrouwen.

Met deze twee herdenkingen had de Britse overheid een oplossing bedacht voor het herdenken van een totale oorlog. De hele Britse samenleving had zich in moeten zetten om de overwinning te behalen, waardoor de voorheen gebruikelijke herdenking van de gesneuvelde (mannelijke) soldaten niet meer voldeed. Tegelijkertijd zorgden deze herdenkingen ervoor dat de rouwenden op indirecte wijze trots konden zijn op hun eigen bijdrage. De overheid maakte duidelijk dat de overwinning alleen behaald was, omdat iedereen zijn steentje had bijgedragen. Ook daarvoor kwam Cavell goed uit. Er waren maar weinig Britse vrouwen geweest die daadwerkelijk in de nabijheid van het front hadden gewerkt. Een aanzienlijk deel had daarentegen wel de banen overgenomen van de vechtende mannen. Net zoals Cavell hadden veel vrouwen dus een alternatieve bijdrage geleverd aan de Britse oorlogsinspanning.

Aan de symbolische functie van Cavell werd dermate veel belang gehecht, dat zelfs voor de eerste Armistice Day al een tweede herdenkingsdag was georganiseerd. Op I7 maart I920 onthulde koningin Alexandra een standbeeld van Cavell, dat de vereeuwiging moest vormen van de nationale dankbetuiging aan Cavell. Voor de locatie van het standbeeld, dat gemaakt was door George Frampton, kozen de Britten voor St. Martin's Lane in Londen. Dit kleine plein ligt naast Trafalgar Square, dat de ultieme openbare plaats is waar Britse helden worden geëerd. Centraal op dit plein staat het standbeeld van Horatio Nelson, de grootste oorlogsheld uit de Britse geschiedenis. Hij had als admiraal eeuwige roem vergaard door in I805 de vloot van Napoleon bij Trafalgar te verslaan, waardoor de Franse invasie van de Britse eilanden verijdeld werd. Vlak voor het gevecht had hij het door hem bedachte vlaggensignaal 'England expects that every man will do his duty' gegeven aan de andere schepen. Tot op de dag van vandaag is deze zin bij de Britten bekend als Nelsons belangrijkste uitspraak.

Voor de Britten had Cavell gehandeld als een ware nakomeling van Nelson, die overigens ook afkomstig was uit de buurt van Norwich. Tijdens haar laatste nacht was ze ter communie gegaan ten overstaan van de Ierse dominee Gahan. 


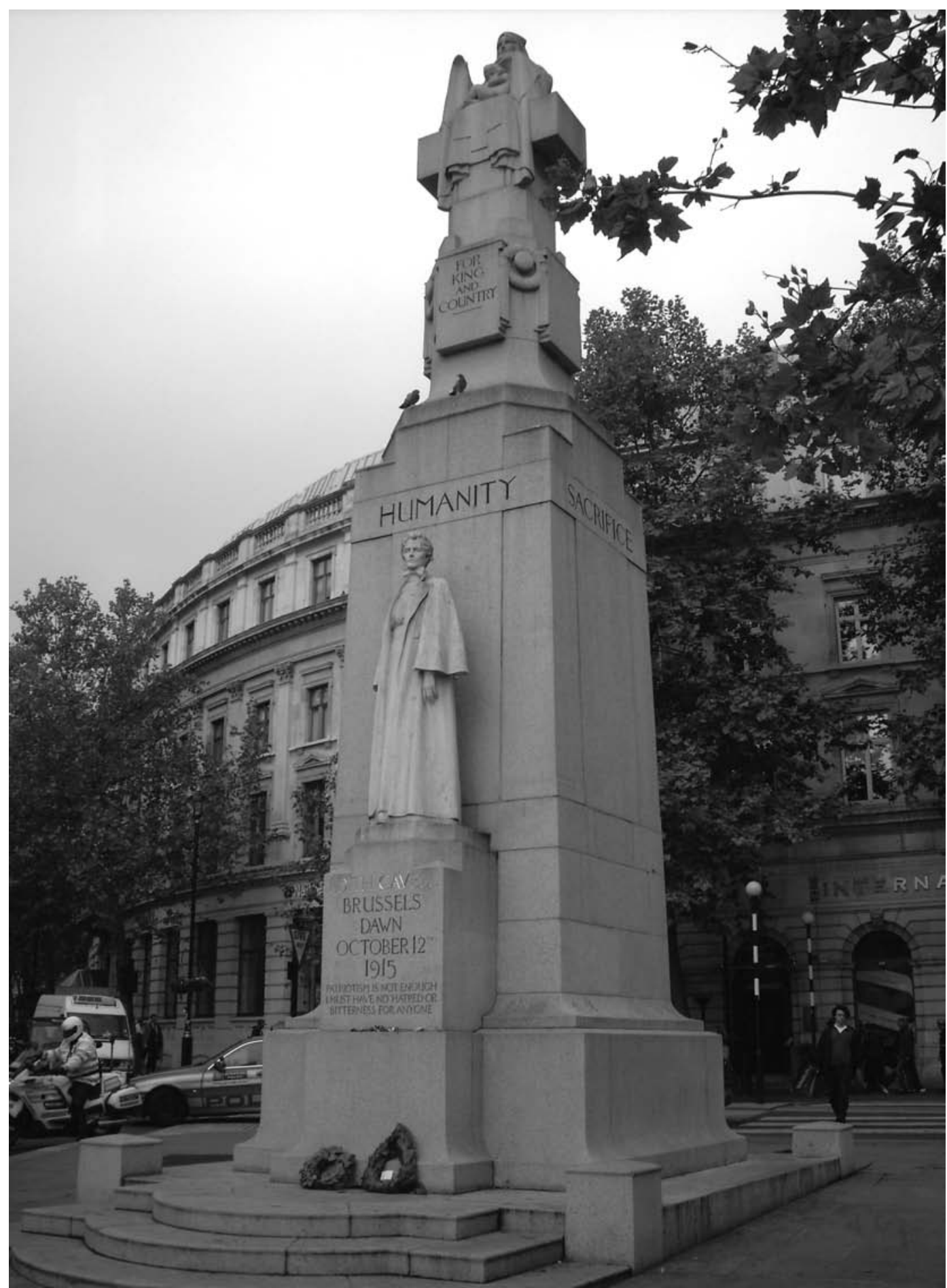

Het standbeeld nabij Trafalgar Square. Foto: Christjan Knijff (2005) 
Ter afsluiting van de ontmoeting zei hij tegen haar: 'We shall always remember you as a heroine and martyr.' Daarop antwoordde Cavell: 'Don't think of me like that, think of me only as a nurse who tried to do her duty. ${ }^{, 26}$ In de context van de oorlog werd deze uitspraak al snel geïnterpreteerd als een verwijzing naar Nelson. Cavell had zogenaamd haar plicht als Britse vervuld door soldaten te laten ontsnappen aan de Duitsers. Deze nationalistische interpretatie was waarschijnlijk niet waar zij op doelde, omdat ze aan zichzelf refereerde als zuster in plaats van Brits burger. Ze was met haar verzetswerk begonnen met het doel om soldaten in leven te houden - in plaats van de mogelijke dood die hen te wachten stond als Duitse krijgsgevangenen. Toch kwam de Britse interpretatie niet helemaal uit de lucht vallen. Vlak voor haar executie werd ze namelijk bijgestaan door dominee Le Seur, tegen wie ze haar laatste woorden uitsprak: 'Ask Mr Gahan to tell my loved ones later that I believe my soul is safe, and that I am glad to die for my country. ${ }^{27}$ Dit werd vervolgens één van de uitspraken waaraan de makers van oorlogsmemorabilia uiteraard gingen refereren ter nagedachtenis van Cavell.

Dat Cavell had gezegd dat ze graag voor haar land wilde sterven, kwam de overheid natuurlijk uitermate goed uit. Deze bevestiging van haar vaderlandsliefde kwam tot uitdrukking in Framptons standbeeld. Op de basis van het imposante voetstuk achter haar staat op elke zijde een karaktereigenschap die met haar geassocieerd werd: Humanity, Devotion, Fortitude en Sacrifice. Hogerop staan de zinsnedes 'For King and Country' en 'Faithful unto Death'. Bovenop het voetstuk had Frampton een zetel gemaakt voor een angel of mercy met een kind in haar armen. Op deze zetel is bovendien het symbool van het Rode Kruis te zien. Zodoende keerden alle elementen terug die al gebruikt waren tijdens de Eerste Wereldoorlog. De portrettering van Cavell ligt ook in dezelfde lijn, omdat Frampton de meer realistische representaties van Cavell als volwassen vrouw had gebruikt als inspiratiebron. De soberheid en rechtlijnigheid van haar figuur geven haar standvastigheid en oprechtheid weer, terwijl de witte kleur haar onschuld benadrukt. Eigenlijk was er dus alleen voor de beschuldigende toon richting Duitsland geen plaats meer na de oorlog. Aan de zelfverheerlijking door de Britten kwam geen einde. Met Cavells standbeeld wilde de Britse overheid de burgers indirect laten zien dat de oorlog een zinvolle nationale onderneming was geweest. De Britten hadden zich net als Cavell van hun beste kant laten zien, waardoor de overwinning een logische gevolg was geweest.

De Britse overheid gebruikte Cavell als symbool voor de traditionele visie op de samenleving en hoopte daarmee nieuwe betekenisgevingen af te remmen of zelfs in de kiem te smoren. Deze poging slaagde gedeeltelijk. De traditionele interpretatie van de oorlog en de Britse maatschappij bleek namelijk niet definitief. Tijdens het verloop van de oorlog had de schijnbaar oneindige massaslachting al menigeen tot inkeer laten komen dat het nationalisme niet de uitkomst bood, die in de zomer van I9I4 werd verwacht. Uit onvrede over het uitblijven van de gewenste resultaten na de oorlog werd de noodzaak tot het formuleren van een 
alternatieve visie steeds groter. Dit proces van verandering vat historicus John Horne samen met de term 'culturele demobilisatie'. ${ }^{28}$ De voormalige tegenstanders demobiliseerden na de militaire beëindiging van de oorlog door ook de politieke en culturele waarden uit deze periode langzaamaan los te laten. De jarenlange indoctrinatie van de zogenaamd onoverbrugbare tegenstellingen tussen de eigen partij en de tegenstander had zijn sporen achtergelaten. Tijdens de culturele demobilisatie zagen politici en burgers in dat de verschillen enorm uitvergroot waren en op een gegeven

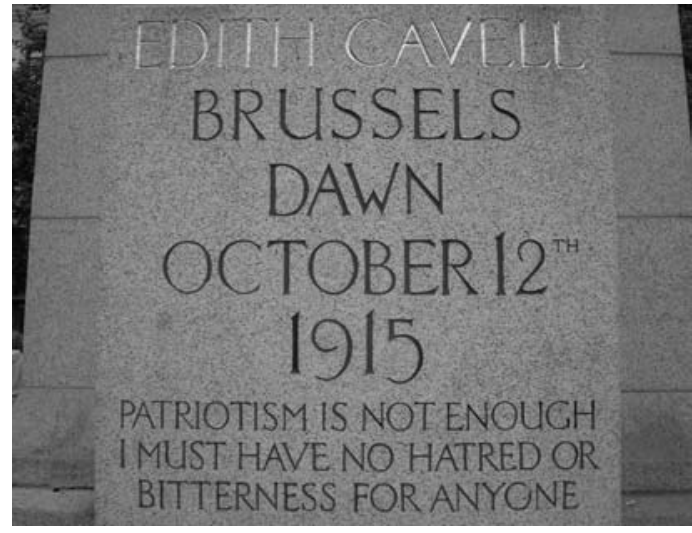

De sokkel van het standbeeld. Foto: Christjan Knijff (2005) moment zelfs nauwelijks meer raakvlakken hadden met de realiteit. Dit proces van inzicht ging stap voor stap, omdat vooroordelen hardnekkig zijn en het veel tijd en energie kost om ze te weerleggen.

Door deze vorm van demobilisatie waren de landen gedwongen om het beeld van hun eigen natie en van de vijand ter herdefiniëren, omdat de simpele tegenstelling tussen 'goed' en 'kwaad' niet meer voldeed. De betekenis van de oorlog veranderde daarmee ook, zodat de oorlog zelf als schuldige voor al het verdriet en verlies aangewezen kon worden. De oorlog werd op die manier geanonimiseerd. De op verzoening gerichte ontwikkelingen op internationaal politiek niveau, na de mislukte bezetting van het Ruhrgebied door Frankrijk en België in I923, zorgden ervoor dat de culturele demobilisatie van 'bovenaf', dat wil zeggen door de staat, gelegitimeerd werd. Het proces van de humanisering van de voormalige vijand vond daardoor op veel grotere schaal plaats. Het stimuleren van de culturele demobilisatie was overigens niet slechts voorbehouden aan de machthebbers. Ook van 'onderaf zorgden burgers met eigen initiatieven voor 'zelfdemobilisatie', net zoals ze zichzelf hadden gemobiliseerd tijdens de oorlog.

In het geval van Cavell leidde dat tot een discussie over haar nalatenschap naar aanleiding van het standbeeld op St. Martin's Lane. Al snel na de onthulling staken de eerste protesten de kop op. De aanleiding daarvoor was een andere uitspraak van Cavell in haar gesprek met Gahan. Ze had hem verteld dat ze berustte in haar lot en niet bang was in de laatste uren van haar leven:

'I have no fear or shrinking. I have seen death so often that it is not fearful or strange to me. (...) And this I would say, standing as I do in view of God and Eternity. I realize that patriotism is not enough. I must have no hatred or bitterness towards anyone. ${ }^{29}$

Meerdere groeperingen waren van mening dat dit Cavells echte boodschap aan de wereld was geweest in plaats van haar vaderlandslievende woorden vlak voor haar executie. Door deze uitspraak niet te vermelden op het standbeeld deed de 
regering Cavell te kort, omdat ze een veel universelere boodschap had verkondigd. Zowel de vrouwenemancipatiebeweging National Council of Women, de socialisten (bij monde van George Bernard Shaw) als de pacifistische beweging Peace Pledge Union onder leiding van de invloedrijke predikant Dick Sheppard, beschuldigden de regering ervan Cavell te willen houden in de sfeer van de vaderlandslievende herdenkingen. Op haar laatste avond was zij juist tot het besef gekomen dat er hogere waarden waren dan patriottisme, waardoor Cavell het zelf oneens zou zijn geweest met de strekking van Framptons standbeeld.

Net zoals degenen die Cavells nagedachtenis interpreteerden vanuit een nationalistisch perspectief, gingen de critici ook selectief te werk. Zo zagen zij voor het gemak Cavells uitspraak vlak voor haar executie over het hoofd, terwijl de overheid de boodschap 'patriotism is not enough' het liefst negeerde. Bovendien was deze uitspraak door Cavell gedaan op het moment dat ze al opgepakt was door de Duitsers. Tijdens haar gevangenisstraf kwam ze tot de conclusie dat vaderlandsliefde alleen niet genoeg was en dat ze zich hier wellicht te veel door had laten leiden. Vooral het begeleiden van net achttienjarige Franse en Belgische jongens over de Nederlandse grens kon wel degelijk geïnterpreteerd worden als een bijdrage aan de geallieerde oorlogsinspanning. Daarnaast vergaten de critici dat de overheid ook niet de uitspraak 'I am glad to die for my country' op het beeld had gezet. De interpretatie van Cavells nagedachtenis werd op die manier nog min of meer opengelaten, al naar gelang de individuele behoeften van de aanwezigen bij de herdenkingen. Daar valt overigens wel weer tegenin te brengen dat de zinsneden 'For King and Country' en 'Faithfull unto Death' eerder inspeelden op nationalistische gevoelens dan op pacifistische.

In ieder geval, de protesten hadden niet direct succes. De opeenvolgende liberale en conservatieve regeringen hadden weinig behoefte om zich iets aan te trekken van de kritiek. Dat veranderde in I924 toen Labour voor een korte periode voor het eerst aan de macht kwam. Veel Britten die meegingen in de opkomende anti-oorlog stemming, maar aansluiting bij een pacifistische beweging te ver vonden gaan, hadden gestemd op deze partij..$^{30}$ Zodoende konden zij toch hun ongenoegens kenbaar maken, zonder echt afstand te doen van hun nationalistische gevoelens. Onder leiding van premier MacDonald erkende de regering de behoefte aan een alternatieve interpretatie en liet een verkorte versie van de uitspraak alsnog op het beeld zetten. Cavells voorbeeldfunctie werd daardoor tweeledig. Ze was een nationale heldin die zich opgeofferd had voor het vaderland én de universele belichaming van het verlangen naar een langdurige vrede.

Op een ander vlak had de overheid wel meer succes. In de jaren na de eerste herdenking ter ere van de terugkeer van de Onbekende Soldaat, verliep de institutionalisering van Armistice Day zonder enig probleem. Elk jaar wilden de Britten op II november een positief signaal aan de overledenen geven dat zij hen nooit zouden vergeten. Bovendien zorgde de herhaling ervoor dat jongere generaties, die de oorlog niet of nauwelijks bewust hadden meegemaakt, ook deze boodschap meekregen..$^{3 \mathrm{I}}$ De herdenkingen van Cavell raakten tegelijkertijd meer 
op de achtergrond. De belangstelling voor haar begrafenis in I9I9 was zeer groot, maar in de daaropvolgende jaren werd de herinnering aan haar steeds meer opgenomen in de algemene herdenking van de oorlog. Armistice Day kreeg een centrale rol in het herinneren aan de Eerste Wereldoorlog. De overheid benadrukte op die dag het heroïsme en de glorieuze opofferingen van alle Britten. Daarbij stonden dan de overleden mannen én vrouwen centraal. Op een veel bescheidener schaal werden in die jaren pogingen ondernomen om de herinnering aan Cavell als individueel slachtoffer levendig te houden. Deze ceremonies gingen voornamelijk uit van meer direct betrokkenen. Lokale overheden zoals de gemeente Norwich of organisaties van zusters organiseerden jaarlijkse bijeenkomsten op I2 oktober.

De afname van de aandacht van de overheid voor Cavell valt volgens historica Tammy Proctor te verklaren uit de wil om de vooroorlogse manier van leven weer op te pakken. ${ }^{32}$ De traditionele rolverdeling tussen mannen en vrouwen moest vanuit sociaal en economisch oogpunt weer benadrukt worden. De veteranen kregen daardoor de gelegenheid hun oude positie weer in te nemen, zodat vrouwen opnieuw de moederrol opgelegd kregen. Dit was onder meer nodig door het dramatisch lage geboortecijfer in de eerste naoorlogse jaren. Daarmee gaf de overheid het signaal dat het werkende bestaan van vrouwen slechts van tijdelijke duur was geweest en dat alleen door de oorlogssituatie een uitzondering was gemaakt. Vanuit dit perspectief valt ook de geringe aandacht voor de werkzaamheden van Cavell te verklaren in de herinneringscultus. Ze moest vooral bekend komen te staan als strijdvaardig slachtoffer, omdat dat in lijn lag met de patriarchale verwachtingspatronen. Haar pionierswerk in België als opgeleide zuster en haar verzetswerk strookten niet met de aan vrouwen toebedeelde rol. Tijdens de oorlog moest deze interpretatie al leiden tot een beroep op mannen: op hun mannelijke karaktereigenschappen. Het lot van Cavell toonde aan dat die mannen de vrouwen in hun samenleving moesten beschermen tegen de vijand, omdat vrouwen niet in staat waren om zichzelf te verdedigen. ${ }^{33}$ De enorme toeloop van vrijwilligers na haar executie toont aan dat deze interpretatie ook tijdens de oorlog door velen werd onderschreven. Toch zorgde een Britse film over Cavell in I928 ervoor dat de overheid nog één keer de discussie met de bevolking en de internationale gemeenschap aan moest gaan, voordat het onderwerp enigszins met rust gelaten kon worden.

In het najaar van I927 kwam de Britse regisseur Herbert Wilcox op het idee om een speelfilm te maken over het laatste levensjaar van Edith Cavell: DAw N. Of hij het ideologisch eens was met de pacifistische interpretatie van haar nagedachtenis valt te betwijfelen, maar hij zag daarin in ieder geval de mogelijkheid om een verhaal te vertellen dat wereldwijd een groot publiek zou kunnen trekken. Daar- 
mee distantieerde hij zich van zijn collega's die al eerder een film hadden gewijd aan Cavell. In de vier films die tussen I9I5 en I9I9 waren verschenen, werd zonder uitzondering gebruik gemaakt van dezelfde tegenstellingen als in de afbeeldingen van Pastien en Corbella. ${ }^{34}$

De meest toepasselijke stijl om dit meer universele perspectief te vertalen naar het filmdoek was realisme. Door een natuurgetrouwe voorstelling van zaken te geven, wilde Wilcox de indruk achterlaten het verhaal op een zo objectief mogelijke manier te vertellen. Naast de directe verteltrant droegen de sobere cameravoering en belichting daar voor een groot deel aan bij. Maar Wilcox greep nog meer mogelijkheden aan. Hij filmde een groot gedeelte op locatie en de personages droegen de juiste kleding uit de Eerste Wereldoorlog. Bovendien bevatte de tweede sequentie louter archiefbeelden van de Duitse inval in België. Er speelde zelfs een toenmalige betrokkene mee, Ada Bodart, die tevens als adviseuse bij het project betrokken was. Daarnaast had Sybil Thorndike als Cavell nagenoeg dezelfde leeftijd als haar personage tijdens de oorlog. Ook in het gebruik van de tussentitels zag Wilcox een kans om de realistische stijl door te voeren. Alle voor het verhaal ter zake doende Duitse documenten werden in nagemaakte vorm getoond, zoals huiszoekingsbevelen, het vonnis van de rechtbank en de correspondentie met de Amerikaanse delegatie.

Door het zorgvuldig geconstrueerde realisme en de vermeende objectiviteit zal DAw N tijdgenoten het gevoel hebben gegeven van een fictieve documentaire. Filmhistoricus Garth Montgomery geeft in zijn analyse van realistische oorlogsfilms uit het Interbellum vanuit een pacifistisch perspectief echter een belangrijk gevolg aan van de boodschap die deze films achterlieten. Doordat de filmmakers afstand deden van de politiek - maar toch een bijdrage wilden leveren aan de nationale herinnering - raakten patriottisme en pacifisme vaak verstrengeld met elkaar. ${ }^{35}$ Wilcox had ook met dit proces te maken. Samen met scenarioschrijver Reginald Berkeley had hij in zijn zoektocht naar een meeslepend einde over het hoofd gezien dat de laatste minuten in het leven van Edith Cavell het meest controversieel waren. Zij wisten dat de muitende soldaat Rammler, het flauwvallen van Cavell en de plichtbewuste Duitse officier voornamelijk waren voortgekomen uit de fantasie van Britse journalisten en de Britse en Belgische bevolking. Toch hadden zij besloten om al deze elementen op te nemen in het verhaal. Het resultaat van deze beslissing om het verhaal op die manier te beëindigen ondermijnde hun beoogde positie van objectiviteit. De keuze voor het tonen van de muitende soldaat was waarschijnlijk met de beste bedoelingen gemaakt. Wilcox en Berkeley wilden geen stereotiepe Hun afbeelden, maar zochten juist de nuance in de afbeelding van Duitsers. Sommigen konden begrip opbrengen voor Cavells humanitaire (verzets)activiteiten, terwijl anderen zich lieten meeslepen in hun eigen nationalisme en militarisme. In het eerste gedeelte van het verhaal functioneren de Duitsers zelfs voornamelijk op de achtergrond. In de tweede helft van de film zijn meerdere Duitsers te zien die meeleven met Cavell. ${ }^{36}$ 


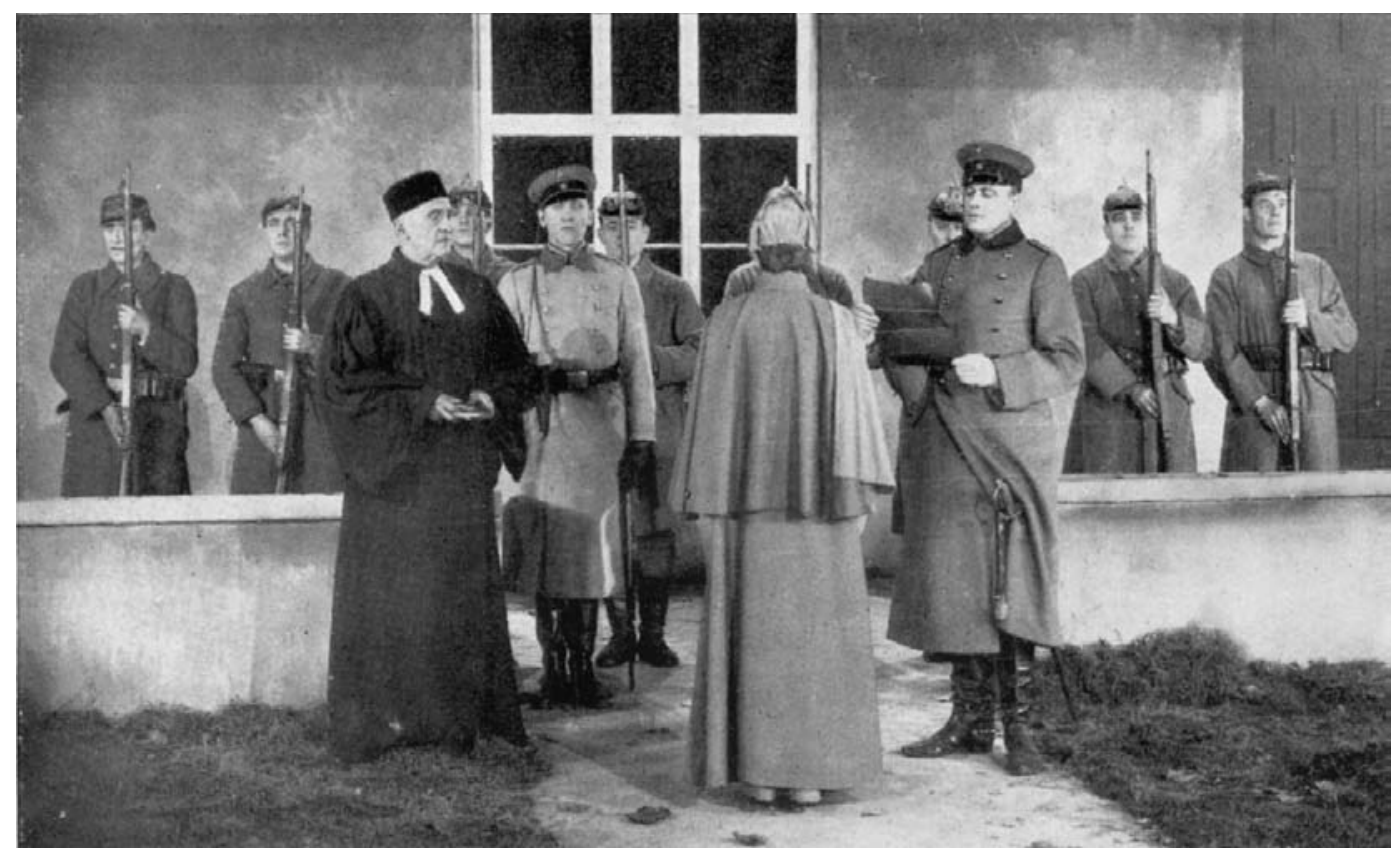

De executie op Tir National. Bron: DAWN (Herbert Wilcox, 1928) / R. Berkeley, Dawn, Londen 1928

Ter verdediging van het controversiële einde geeft Berkeley in het voorwoord van zijn gelijknamige boek aan dat hij een historisch verhaal heeft willen schrijven:

'My book, however, is a work of fiction. That is to say, it is an attempt at reconstructing the story as I think it may have happened. (...) To have adhered meticulously to incidents and people would have made this book what it was not intended to be, a biography. ${ }^{37}$

Berkeley beriep zich dus op zijn artistieke vrijheid in het vertellen van het verhaal over Cavell. In de manier waarop hij de geschiedenis benaderde, was hij zeker niet de enige. Veel schrijvers van historische romans en literaire biografieën waren in de jaren twintig van mening dat de ware persoonlijkheid van hun hoofdpersoon alleen tot haar recht kwam door intuïtieve psychologische toevoegingen. Veel gebeurtenissen in hun verhalen waren louter fictief en hadden als functie om de heldenstatus van de hoofdpersoon te bevestigen. Hierdoor vond een opleving van de waardering van de autonome persoonlijkheid plaats. Dit was een romantische reactie op het gevoel van anonimiteit tijdens de oorlog en de opkomende massacultuur na de oorlog. ${ }^{38}$ Deze tendens was dus niet alleen in de literatuur (en geschiedschrijving) op te merken. De conservatieve instelling van de filmindustrie en haar pogingen om zo veel mogelijk toeschouwers te trekken, zorgden ervoor dat filmmakers voornamelijk gebruik maakten van 
Cavell geeft de ondergedoken soldaten te drinken. Bron: DAWN (Herbert Wilcox, 1928) / R. Berkeley, Dawn, Londen 1928

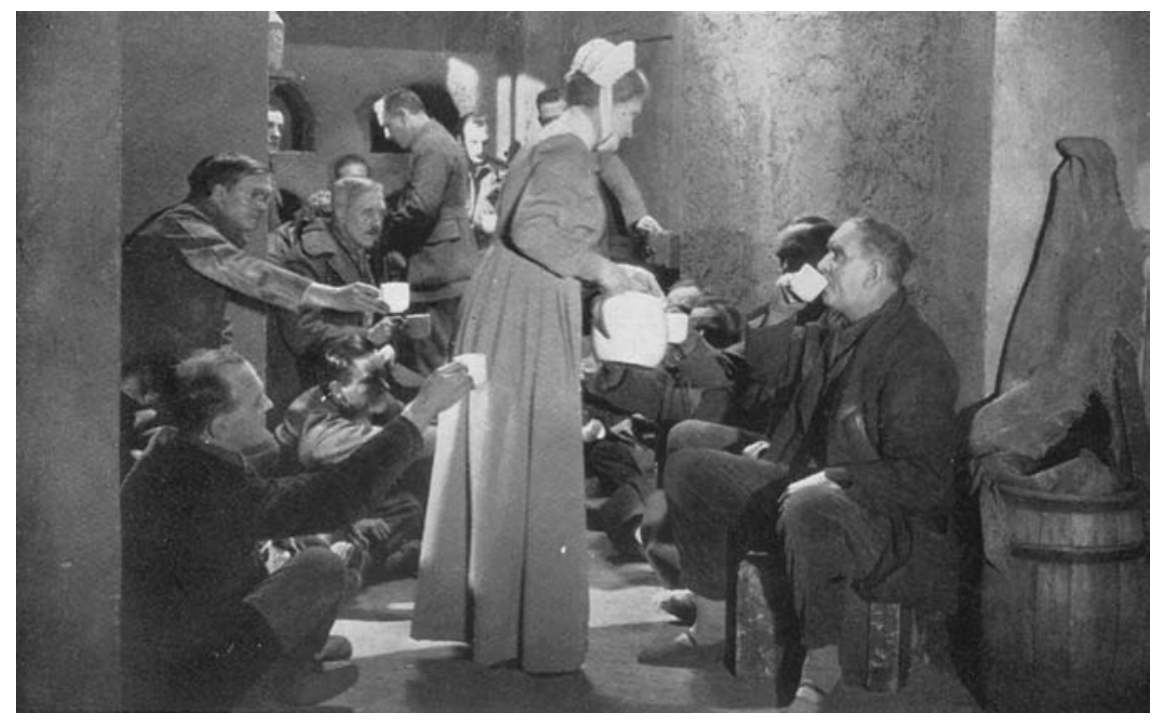

traditionele manieren om hun verhaal te vertellen. Daarnaast hadden de successen van de eerdere films over Cavell aangetoond op welke manier toeschouwers haar verhaal het liefst verteld zagen. Wilcox en Berkeley grepen terug op een oude formule, terwijl het bij hen min of meer bekend was dat de geruchten niet klopten en dat elke representatie van een militaristische Duitser minder gewenst was dan voorheen.

De romantische benadering van Cavell als volledig autonoom opererend hoofdpersoon benadrukte alleen wel de tragiek van haar dood. De simplificatie van de gebeurtenissen zorgde ervoor dat zij veel meer op de voorgrond kwam te staan. In werkelijkheid was ze niet de spil van de verzetsbeweging geweest, maar één van de vele participanten. Wilcox en Berkeley waren lang niet de enigen die zich daar schuldig aan maakten. De reputatie van Cavell was, zeker in Engeland, onomstreden. Voor een echte ontmanteling van de oorlogscultuur is echter naast de humanisering van de voormalige vijand ook de relativering nodig van de zogenaamde superioriteit van de eigen natie. De verering van martelaars was onlosmakelijk verbonden aan de oorlogscultuur en werkte de culturele demobilisatie tegen. Wilcox en Berkeley probeerden in DAwn Duitsers genuanceerd weer te geven, maar tegelijkertijd werd Cavell onomwonden vereerd als een kruising tussen Maria en Jezus Christus.

Het eerste gedeelte van de film legt de nadruk op haar rol als moeder, terwijl ze eigenlijk nog een maagd en ongehuwd was. Door deze verwijzing naar Maria riep de representatie van Cavell allerlei positieve associaties op die bij iedereen bekend waren. Dit aspect wordt veelvuldig benadrukt. Ze voert haar activiteiten voornamelijk in het ziekenhuis uit en komt weinig buiten de deur. Haar werkzaamheden voor het verzet zijn dus van typisch vrouwelijke aard. Door deze interpretatie creëerden Wilcox en Berkeley wel de mogelijkheid om meer uit te 
weiden over haar verzetswerk dan gebruikelijk was. Hun benadering bracht de traditionele rolverdeling namelijk niet in gevaar. De vergelijking met Jezus gaat door deze interpretatie in het eerste gedeelte van de film maar ten dele op. In algemene zin streden Cavell en Jezus met gevaar voor eigen leven voor de mensheid, maar de manier waarop ze hun taak uitvoerden verschilde. Cavell beperkte zich in DAw N tot datgene wat van vrouwen werd verwacht, terwijl Jezus als man meer mogelijkheden had om zijn taak uit te voeren.

De overeenkomsten zijn groter in het tweede gedeelte van de film, met name door haar arrestatie, rechtszaak en executie. Tijdens de rechtszaak houdt Cavell zich groot en toont ze zich een ware martelares. Nadat het vonnis is geveld doet ze geen verzoek tot gratie, waardoor haar opoffering voor haar idealen volledig is. De religieuze verwijzing komt vervolgens het best naar voren tijdens haar laatste nacht. De Engelse dominee houdt een speciale mis voor Cavell in haar cel. Het ter communie gaan krijgt daardoor dezelfde waarde als het Laatste Avondmaal. De daaropvolgende executie kan gezien worden als de moderne variant op de kruisiging van Jezus. Tijdens deze laatste scène combineert Wilcox zijn interpretaties van Cavell als martelares, heldin en maagdelijk moederfiguur. Cavell wil geen blinddoek om, waardoor haar status als heldin benadrukt wordt: ze durft de dood in de ogen te kijken. Maar op het allerlaatste moment krijgen haar vrouwelijke eigenschappen toch de overhand en valt ze van alle spanning flauw.

Ondanks de goede bedoelingen van Wilcox werd DAwN in eerste instantie nauwelijks beoordeeld op zijn artistieke kwaliteiten. Direct na het eerste bericht in een Britse krant over Wilcox' project in september I927 bracht de Duitse ambassade de kwestie ter sprake bij het Britse ministerie van Buitenlandse Zaken. Daar kreeg Duitsland te horen dat de Britse overheid geen bevoegdheden had om een film te censureren. Om hun ongenoegen te kunnen ventileren, raadde het ministerie hen aan om contact op te nemen met Wilcox zelf. Het Duitse verzoek was overigens geen ongebruikelijke stap, omdat het Duitse buitenlandbeleid erop gericht was om films met een (vermeende) anti-Duitse strekking in andere landen verboden te krijgen. Al tijdens het laatste jaar van de Eerste Wereldoorlog had Duitsland een voorstel gemaakt om de distributie van de zogenaamde 'Hetzfilm' te verbieden.

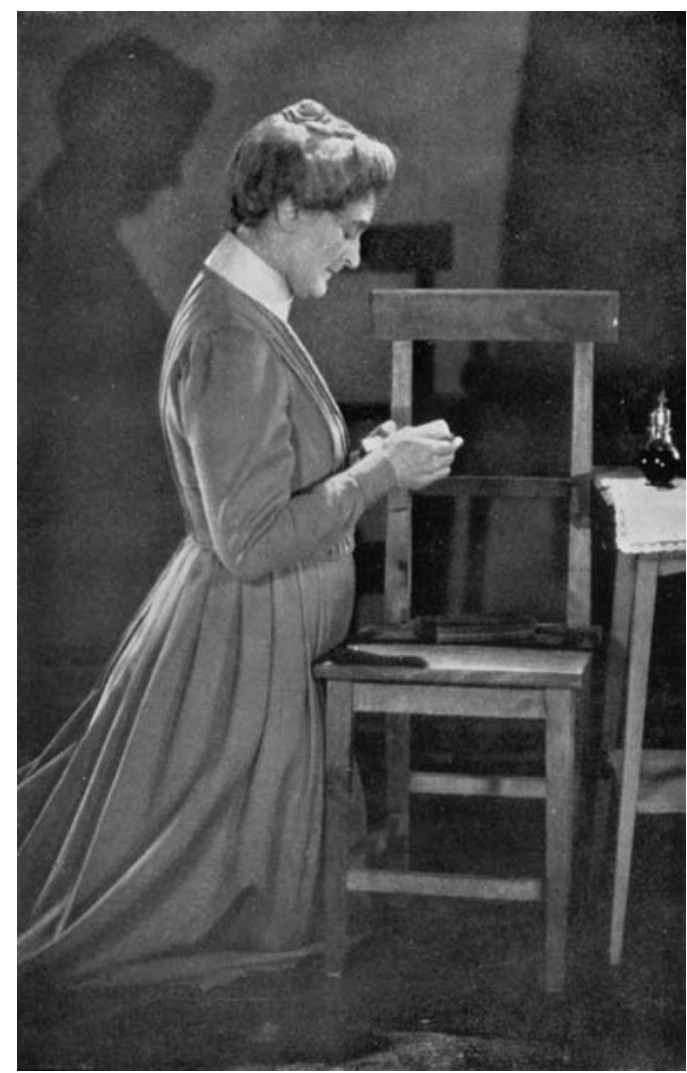

Cavell gaat ter communie in de gevangenis. Bron: DAWN (Herbert Wilcox, 1928) / R. Berkeley, Dawn, Londen 1928 
Duitsland was zich bewust van het (vermeende) succes van de geallieerde propaganda en hoopte na de oorlog de beeldvorming over Duitsland te kunnen beïnvloeden. Maar door de gedwongen afwezigheid bij de besprekingen van Versailles en de Volkenbond, kreeg Duitsland niet de kans het voorstel in te dienen. Vandaar dat Duitsland via zijn diplomaten en politici invloed probeerde uit te oefenen op de distributie en vertoning van potentieel schadelijke films. In eigen land wierp deze tijdrovende bezigheid zijn vruchten af, maar in het buitenland was het succes uiterst gering. De invloed van de Duitse diplomaten in de internationale politiek was nog beperkt. Belangrijker nog was de overtuiging van veel landen dat Duitsland zich ongewenst mengde in interne politieke aangelegenheden. Toch zetten de Duitsers tegen beter weten in dit beleid voort. Zij zagen in niets doen een vorm van acceptatie van het bevooroordeelde geallieerde beeld van Duitsland. ${ }^{39}$

Het Duitse verzoek tot een verbod op DAw N was toch uitzonderlijk, omdat de film zich nog in de productiefase bevond. Duitsland wist niet wat de strekking zou worden van de film, maar vond het verfilmen van de gebeurtenissen rond Edith Cavell al bezwaarlijk genoeg. De Engelse verklaring betekende dan ook niet het einde van de Duitse inspanningen. Omdat diplomaten van lagere rang er niet in slaagden om Wilcox af te laten zien van de voortzetting van de productie, nam de Duitse minister van Buitenlandse Zaken Gustav Stresemann het heft in handen. Stresemann wilde elk risico uitbannen dat DAw N de onderhandelingen zou beïnvloeden tussen Frankrijk, Groot-Brittannië en zijn eigen land, zoals die gaande waren sinds het Pact van Locarno uit I925. Hij besprak in november de kwestie met de Britse ambassadeur in Berlijn, die vanuit Londen de instructies had gekregen om het al eerder ingenomen standpunt nogmaals over te brengen. Duitsland accepteerde dit advies en nam contact op met Wilcox. In samenspraak leidde dit contact tot een aantal aanpassingen in scènes waartegen de Duitsers bezwaar hadden..$^{\circ}$

De gesprekken tussen de Engelse en Duitse overheid lekten echter uit, waarna Austen Chamberlain, de Britse minister van Buitenlandse Zaken, in de daaropvolgende maanden meerdere malen ter verantwoording werd geroepen in het Lagerhuis. Chamberlain ontkende stelselmatig elke betrokkenheid van Duitsland in de Britse binnenlandse politiek, maar sprak ondertussen wel publiekelijk zijn afkeer uit over Wilcox' film. In februari I928 liet hij weten het verhaal van Cavell nog niet voor verfilming geschikt te achten. Haar executie en de daaropvolgende discussie lagen voor de direct betrokkenen en de rest van de wereld nog te vers in het geheugen. Als er dan per se een film over moest komen, dan pas als de laatste betrokkene was komen te overlijden. ${ }^{4 \mathrm{I}}$ Uit zijn reactie was te merken dat Chamberlain het relatief nieuwe medium film niet wilde aanvaarden als volledig geaccepteerde uitgaansvorm. In zijn optiek bestond de filmwereld enkel en alleen uit mensen die op financieel gewin uit waren. Deze poging om DAwn bij voorbaat in diskrediet te brengen met zijn gezag als vooraanstaand politicus en winnaar van de Nobelprijs voor de Vrede, slaagde maar gedeeltelijk. 
Twee dagen na Chamberlains mededeling had de British Board of Film Censors, een adviesorgaan voor de plaatselijke keuringscommissies, namelijk al besloten de film niet goed te keuren op grond van 'inexpediency'. Dit wekte de indruk dat Chamberlain contact met hen had gehad en erop had aangedrongen de film zo snel mogelijk te verbieden, zodat de zaak afgehandeld zou zijn.

$\mathrm{Na}$ deze opmerkelijke gebeurtenis voelden veel opiniemakers en betrokkenen, die de film al in besloten voorstellingen hadden gezien, zich gedwongen om partij te kiezen. Door de commotie die dat teweegbracht, moest Chamberlain weer in het Lagerhuis verschijnen. Tijdens de tweede dag van het debat over DAWN, op 29 februari, kon Chamberlain uiteindelijk niets anders meer dan toegeven dat Duitse verzoeken tot (gedeeltelijke) censuur min of meer gebruikelijk waren in de diplomatie. Maar, zo stelde Chamberlain, ook Groot-Brittannië had in de afgelopen jaren een aantal soortgelijke verzoeken ingediend. ${ }^{42}$ Deze verzoeken richtten zich voornamelijk op films die schade zouden kunnen toebrengen aan het prestige en imago van Groot-Brittannië. Deze mededeling leidde onder de politici en het Britse volk tot meer begrip voor de Duitse actie, omdat hun eigen land zich buiten het publieke gezichtsveld ook had gemengd in interne aangelegenheden van andere landen. Dit impliceerde overigens niet dat de geheimhouding over deze vorm van censuur en Chamberlains handelen door hen werd goedgekeurd.

Wilcox probeerde ondertussen DAWN alsnog in het buitenland vertoond te krijgen en hij boekte succes in België. De Belgische minister van Buitenlandse Zaken Paul Hymans had al eerder laten weten geen bevoegdheid te hebben om de film te verbieden, ondanks de verwoede protesten van de Duitse ambassadeur. ${ }^{43}$ Tussen de regels door liet hij echter merken daar ook niets voor te voelen, ook al zou hij deze bevoegdheid wel hebben. Deze andere opstelling ten opzichte van DAwn dan zijn Britse collega was het resultaat van het verschil in oorlogsculturen tussen beide landen. Een belangrijke factor daarin was de wijze waarop de oorlog beleefd werd door de twee landen. België voelde zich groot onrecht aangedaan door de inval van Duitsland, waarna een periode van bezetting volgde die gepaard ging met een steeds harder terreurbewind. De invloed van de oorlog was daardoor zeer groot op de hele Belgische maatschappij, zodat het onderscheid tussen het front en het thuisfront moeilijk te maken was. In Groot-Brittannië was de oorlogservaring daarentegen minder heftig. Door de totale oorlog waren de Britse burgers doordrongen van het feit dat hun land in oorlog was, maar de persoonlijke ervaring daarmee was minder ingrijpend. Voor de Britten was er nog wel een duidelijk onderscheid tussen beide fronten. Deze scheiding was in letterlijke zin zelfs geografisch: het Kanaal verdeelde de Britse samenleving in soldaten en burgers.

Dit verschil in persoonlijke ervaring met de oorlog zorgde tijdens de periode van culturele demobilisatie voor een verschil in bereidwilligheid in het loslaten van de tegenstellingen. Deze bereidwilligheid bepaalde het tempo en de omvang van de demobilisatie. In die zin is het ook niet vreemd dat de Belgen gro- 
tere moeite hadden om met meer afstand naar de oorlog te kijken dan de Britten. Dat wil overigens niet zeggen dat alle Britten volledig participeerden in dit proces. Het grote verschil tussen Groot-Brittannië en België was de opstelling van de politici en andere personen met macht. Zij waren degenen die het proces aanstuurden en het in zekere mate op konden leggen. In België bleek deze groep mensen minder cultureel gedemobiliseerd dan in Groot-Brittannië.

Vandaar dat het niet verbazingwekkend is dat de wereldpremière van DAWN plaatsvond in België. In een uitverkocht Agora, de grootste bioscoop van Brussel, bevonden zich onder de 2600 aanwezigen veel politici, journalisten, oorlogsinvaliden en zusters. ${ }^{44}$ DAw werd over het algemeen positief ontvangen en de vertoning verliep vrijwel vlekkeloos. Het luide applaus aan het einde maakte duidelijk dat het premièrepubliek DAwn kon waarderen. Heel erg verwonderlijk was deze algemene goedkeuring niet, omdat Edith Cavell met haar strijd tegen de bezetter ook voor de Belgen een heldin was geworden. In tegenstelling tot de Britten waren zij minder bereidwillig om rekening te houden met Duitsland, waardoor ze openlijk hun goedkeuring voor de film konden uitspreken.

Andere landen waren echter terughoudender. Zij durfden zich pas te buigen over de film, nadat de belangrijkste plaatselijke keuringscommissie in GrootBrittannië, de London County Council, een oordeel had geveld. Deze commissie keurde de film in april met een minieme meerderheid goed en zette daarmee de toon voor de wereldwijde vertoning van DAwN. Verrassenderwijs sprak ook Duitsland zich uit voor de vertoning van de film. Kennelijk was het standpunt van de Britse regering een bevestiging van de goede bedoelingen ten opzichte van Duitsland, ook al vond de vertoning van DAw daar uiteindelijk doorgang. In februari hadden Duitse politici en journalisten namelijk nog te kennen gegeven het oordeel van Chamberlain toe te juichen. ${ }^{45}$ Maar toen de film vanaf eind juni in de Duitse bioscopen verscheen, schreven veel journalisten zelfs licht goedkeurend tot enthousiast over DAwn. ${ }^{46}$ Extreem-rechts had wel grote bezwaren tegen de vertoning vanwege de interpretatie van de hele affaire en de weergave van het leger. Het filmvakblad Film Kurier waarschuwde voor de verschillen in perceptie door verschillende nationaliteiten. In Duitsland mocht de film dan wel over het algemeen goed ontvangen zijn, toch bracht de film schade toe aan de internationale betrekkingen. Film Kurier verwachtte dat de vertoning bij Duitslands voormalige vijanden toch weer haat zou oproepen, die 'door Ioo toespraken in Genève niet weer goed te maken' zou zijn. ${ }^{47}$

Pas nadat de discussie over de geschiktheid van de film was afgerond, volgden de recensies over de artistieke kwaliteiten van DAwn. Zelfs menig tegenstander van vertoning moest toegeven dat Wilcox zijn onderwerp met gepaste afstandelijkheid had benaderd. De soberheid sprak commentatoren aan en ronduit lof was er voor de acteerprestatie van Thorndike. Ondanks dat de filmkritiek in I928 nog in volle ontwikkeling was, kwam al wel een aantal criteria voor de beoordeling van oorlogsfilms naar voren. Een goede oorlogsfilm moest documentairemateriaal bevatten, stilistisch een eenheid vormen en historisch 
betrouwbaar zijn. ${ }^{48}$ DAwn voldeed aan de eerste twee punten, maar over het laatste punt bestond onenigheid. Dit werd ook aangegrepen door verschillende keuringscommissies, omdat in hun ogen de executiescène in strijd was met de goede zeden. In dat geval hadden de filmkeurders een legitieme reden om enkele segmenten uit de film te laten knippen. De historische betrouwbaarheid van de laatste scène werd door velen niet volledig in twijfel getrokken, zodat DAWN nog relatief ongeschonden het bioscooppubliek bereikte. In Groot-Brittannië was de film in ieder geval een succes, maar gegevens over andere landen zijn (nog) niet voorhanden. Uiteindelijk vond het merendeel van de internationale gemeenschap 'The spirit of Locarno' en de staat van culturele demobilisatie stabiel genoeg voor de verfilming van een controversiële oorlogsgebeurtenis, ondanks de bezwaren van zwaargewichten Chamberlain en Stresemann.

\section{Conclusie}

De wereldwijde bekendheid die Edith Cavell pas na haar dood kreeg, maakte haar tot een uiterst bruikbaar symbool waarmee de reden tot het voeren van de Eerste Wereldoorlog duidelijk kon worden gemaakt. Net zoals de bevolking hadden de Britse journalisten zich cultureel gemobiliseerd, waardoor zij niet onderkenden dat de Duitsers eventueel legitiem hadden gehandeld door Cavell te executeren. In plaats daarvan interpreteerden zij en andere opiniemakers het incident vanuit een bevooroordeeld perspectief. Door Cavell te representeren als jong en onschuldig meisje toonden zij de barbaarsheid van de Duitse bevolking aan, die te allen tijde bestreden moest worden door de verlichte westerse wereld. Daarnaast functioneerde de representatie van Cavell als volwassen vrouw en moeder als bevestiging van de superioriteit van de eigen natie en haar bondgenoten.

$\mathrm{Na}$ de militaire beëindiging van de oorlog nam de noodzaak langzamerhand af om de voormalige vijand Duitsland af te schilderen als een inferieur volk. Daardoor verloor de weergave van Cavell als jong en onschuldig meisje aan zeggingskracht, in tegenstelling tot haar andere representatie. De Britten hadden zich van hun beste kant laten zien door in de Eerste Wereldoorlog nobel en eervol te vechten. Dit ging niet alleen op voor de soldaten aan het front, maar ook voor alle burgers die een alternatieve bijdrage hadden geleverd aan de oorlogsinspanning. Omdat het leven van Cavell meer gelijkenissen vertoonde met de oorlogservaring van de burgers dan met die van de soldaten, kreeg de rol van Cavell als het symbool voor de participerende burgers meer nadruk. Ze verloor daarmee wel haar functie als boegbeeld voor de emancipatie van vrouwen. Daar was geen behoefte meer aan in het naoorlogse Groot-Brittannië, waar men hevig probeerde om de traditionele rolverdeling te herstellen.

Toch was de representatie van Cavell als vaderlandslievende heldin niet definitief. In de loop van de jaren twintig vond de culturele demobilisatie op steeds 
grotere schaal plaats, waardoor de negatieve aspecten van de Eerste Wereldoorlog meer nadruk kregen. Niet alleen Duitsland was de oorzaak van al het verdriet en verlies, maar alle landen die zich in de oorlog hadden gemengd. De oorlog zelf werd als schuldige aangewezen. Die analyse had Cavell tijdens haar gevangenschap ook al gemaakt, waardoor zij een nieuwe rol kreeg toebedeeld door allen die geen genoegen namen met de eenzijdige interpretatie van de oorlog door de Britse overheid. Als universeel symbool voor een langdurige vrede kon de executie van Cavell daardoor tien jaar na de start van de vredesbesprekingen aangegrepen worden door een filmmaker om de desastreuze gevolgen van oorlog voor de mensheid aan te tonen.

Lang niet iedereen was overtuigd van de nieuwe rol van Cavell in het proces om betekenis te geven aan de Eerste Wereldoorlog. Vooral politici reageerden afwijzend op het initiatief van Wilcox. Allereerst hadden ze nog niet genoeg vertrouwen in de algemene bereidwilligheid onder de bevolking om afstand te doen van de oorlogscultuur, waardoor zij een ouderwetse 'Hetzfilm' verwachtten. Daarnaast heerste onder hen nog steeds wantrouwen ten opzichte van het 'ordinaire' nieuwe medium film. Zonder dat zij, en de voorstanders van de film, daar zelf erg in hadden, kregen ze gelijk. De representatie van Duitsland in DAWN was redelijk genuanceerd, maar de weergave van Cavell stamde nog uit de periode van culturele mobilisatie. Als symbool voor de Britse natie en de voormalige bondgenoten bleef zij een heldin en heilige op wie niets viel aan te merken. Op het hoogtepunt van de internationale verzoeningspolitiek tijdens het Interbellum kon de vertoning van DAw N dan wel doorgang vinden - toch werd duidelijk dat de Eerste Wereldoorlog op korte termijn voor een nagenoeg onoverbrugbare culturele tweedeling had gezorgd tussen de winnaars en de verliezers.

\section{Noten}

I M.L. Sanders en P.M. Taylor, British propaganda during the First World War, 1914-18, Londen I982, p. I8.

2 D. Welch, Germany, propaganda and total war, 1914-1918, New Brunswick 2000, p. 26.

3 Sanders en Taylor, British propaganda, p. 3I.

4 Idem, p. I55.

5 R. Ryder, Edith Cavell, Londen I975, p. 25I-252.

6 S. de Schaepdrijver, De Groote Oorlog: het koninkrijk België tijdens de Eerste Wereldoorlog, Amsterdam I997, p. I24.

7 Idem; Ryder, Edith Cavell, p. 225.

8 T. Wilson, The myriad faces of war. Britain and the Great War, 1914-1918, Cambridge I986, p. 747.

9 F. Boterman, Moderne geschiedenis van Duitsland 1800-1990, Amsterdam I996, p. 35-36.

Io J. Horne (ed.), State, society and mobilization in Europe during the First World War, Cambridge I997, p. 3 .

II C. Speck, 'Edith Cavell: martyr or patriot', in: Australian and New Zealand Journal of Art 2, no. I, 200I, p. 83 . 
I2 T.M. Proctor, Female intelligence. Women and espionage in the First World War, New York 2003, p. I07; A.C. Hughes, 'War, gender and national mourning: The significance of the death and commemoration of Edith Cavell in Britain', in: European Review of History - Revue européenne d'Histoire, no. 3, 2005 , p. 430.

I3 C. Collins Shadox, 'The martyrdom and myth of Edith Cavell', in: Connecticut Nursing News, maart-mei I999.

I4 P.A. Kalisch en B.J. Kalisch, The changing image of the nurse, Reading I987, p. 22.

I5 R. Cork, A bitter truth. Avant-garde art and the Great War, New Haven I994, p. I89.

I6 A. Becker, La guerre et la foi: de la mort à la mémoire 1914-1930, Parijs I994.

I7 Speck, 'Edith Cavell: martyr or patriot', p. 83-98.

I8 Proctor, Female intelligence, p. I06.

I9 A. Warwick, Women at war 1914-1918, Londen I977, p. I09. In de brochure De dood van Edyth Cavell (auteur onbekend, Amsterdam I9I5) staat de datum van de uitspraak vermeld: 2 november I9I5; Hughes, 'War, gender and national mourning', p. 43I. Hughes gaat verder in op de uitspraak van Asquith. Hij zei namelijk ook dat Cavell 'a worse ordeal than the battlefield' het hoofd had moeten bieden. Haar interpretatie is dat Asquith daarmee Cavell boven de gewone soldaten plaatste. Soldaten konden zich tenminste nog verdedigen in een gevecht, terwijl Cavell ongewapend tegenover het vuurpeloton had gestaan.

20 P. Fussell, The Great War and modern memory, New York I975, p. 233.

2I G. Mosse, Fallen soldiers: reshaping the memory of the World Wars, New York I990, p. I26.

22 L. Engelen, De verbeelding van de Eerste Wereldoorlog in de Belgische speelfilm, Leuven 2005, hoofdstuk 4, p. 2 (niet gepubliceerd).

23 J. Winter, Sites of memory, sites of mourning. The Great War in European cultural history, Cambridge I995.

24 Idem, p. 2.

25 T. Holt en V. Holt, Till the boys come home. The picture postcards of the First World War, Londen I977, p. I70.

26 Ryder, Edith Cavell, p. 2I4.

27 A.E. Clark-Kennedy, Edith Cavell. Pioneer and patriot, Londen I965, p. 224

28 J. Horne, 'The European moment between the two world wars (I924-I929)', in: M. de Keizer en S. Tates (red.), Moderniteit. Modernisme en massacultuur in Nederland 1914-1940, Amsterdam 2004 , p. 228.

29 S. Upjohn, Edith Cavell. The story of a Norfolk nurse, Norwich 2000, p. 4I.

30 P. Brock, Twentieth-century pacifism, New York I970, p. Io9.

3I M. Connelly, The Great War, memory and ritual. Commemoration in the city and east London, 1916-1939, Woodbridge 2002, p. 45 en p. I62.

32 Proctor, Female intelligence, p. I2I.

33 Idem, p. Io6.

34 Nurse and martyr (Percy Moran, Groot-Brittannië, I9I5), The MARTYrdom of NuRSE CAVEll (regisseur onbekend, Australië, I9i6), THE CAVell CaSE (John Adolfi, Verenigde Staten, I9I8) en THE GREAT VICTORY, WILSON OR THE KAISER? THE FALL OF THE HOHENZOLLERNS (Charles Miller, Verenigde Staten, I9I9).

35 Garth Montgomery, 'Realistic' war films in Weimar Germany: entertainment as education', in: Historical Journal of Film, Radio and Television, nr. 2, I989, p. II6.

36 J. Robertson, 'DAwn (I928): Edith Cavell and Anglo-German Relations', in: Historical Journal of Film, Radio and Television, nr. 4, I984, p. 24-25.

37 Reginald Berkeley, Dawn, New York I928, p. xxxviii.

38 H.W. von der Dunk, De verdwijnende hemel. Over de cultuur van Europa in de twintigste eeuw, deel I, Amsterdam 2000, p. 470-473.

39 T.J. Saunders, 'German diplomacy and the war film in the I920s', in: K. Dibbets en B. Hogenkamp (red.), Film and the First World War, Amsterdam I995, p. 213 e.v.

40 Robertson, 'DAwn (I928)', p. I8. Robertson vermeldt niet welke scènes gewijzigd zijn.

4I De Maasbode, II februari I928. 
42 Robertson, 'DAwn (I928)', p. I6.

43 Nieuwe Rotterdamsche Courant, II en I2 februari I928.

44 Nieuw Weekblad voor de Cinematografie (NWC), 23 maart 1928.

45 Morning Post, 2I februari 1928; Le Soir, 23 februari 1928.

46 NWC, 6 juli i928. Dit staat ook vermeld in Robertsons artikel.

47 Idem, 28 juli I 928.

48 B. Kester, Film front Weimar. Representations of the First World War in German films of the Weimar Period (1919-1933), Amsterdam 1998, p. 224. 